NBER WORKING PAPER SERIES

\title{
PATENTS, PRICE CONTROLS AND ACCESS TO NEW DRUGS: HOW POLICY AFFECTS GLOBAL MARKET ENTRY
}

\author{
Jean O. Lanjouw \\ Working Paper 11321 \\ http://www.nber.org/papers/w11321 \\ NATIONAL BUREAU OF ECONOMIC RESEARCH \\ 1050 Massachusetts Avenue \\ Cambridge, MA 02138 \\ May 2005
}

The views expressed herein are those of the author(s) and do not necessarily reflect the views of the National Bureau of Economic Research.

(O2005 by Jean O. Lanjouw. All rights reserved. Short sections of text, not to exceed two paragraphs, may be quoted without explicit permission provided that full credit, including $\odot$ notice, is given to the source. 
Patents, Price Controls and Access to New Drugs: How Policy Affects Global Market Entry

NBER Working Paper No. 11321

May 2005

JEL No. L1, I1

\section{ABSTRACT}

Efforts to strengthen the global patent system for pharmaceuticals continue to be controversial, and what will likely be a similarly fraught international debate over price controls has begun. The outcome of international negotiations and the resulting policy decisions made by each country will have many ramifications - influencing the size of future investment in medical research, the availability of the resulting therapies, how the financial burdens are distributed across countries, and finally the health of consumers. This paper considers how legal and regulatory policies affect whether new drugs are marketed in a country, and how quickly. Less than one-half of the new pharmaceutical molecules that are marketed worldwide are sold in any given country, and those that are sold are often available to consumers in one country only six or seven years after those in another. Both price regulation and intellectual property rights influence these outcomes. The analysis covers a large sample of 68 countries at all income levels and includes all drug launches over the period 1982-2002. It uses newly compiled information on legal and regulatory policy, and is the first systematic analysis of the determinants of drug launch in poor countries.

Jean O. Lanjouw

Brookings Institution

1775 Massachusetts Avenue, NW

Washington, DC 20036

and NBER

lanjouw@are.berkeley.edu 


\section{Introduction}

The pharmaceutical industry faces a rapidly evolving legal and regulatory environment.

Governments, drug companies and advocacy groups continue to engage in a decade-long battle over the type of patent rights that will be available to industry, particularly in poor countries. Particular criticism has focused on the intellectual property standards required of members of the World Trade Organization-standards known as Trade-Related aspects of Intellectual Property, or TRIPS, rules. International drug pricing is also coming under the spotlight. Americans have accused the Europeans and Canadians of using their price control systems to free-ride on U.S. consumers, and the United States is starting to push for regulatory changes in bilateral trade negotiations. ${ }^{2}$ These pressures may well generate future reforms on a broad scale.

The choices made by each country about its patent system and price regulation will have many ramifications - influencing the size of future investment in medical research, the availability of the resulting therapies, how the financial burdens are distributed across countries, and finally the health of consumers. We focus here on how policy choices affect whether new drugs are marketed in a country, and how quickly. Because there are fixed costs associated with launching new products, it would seem intuitive that both weaker price regulation and stronger intellectual property would facilitate entry by virtue of increasing firm profit. $^{3}$ However, what makes this an interesting economic problem is that intellectual property can have a second

\footnotetext{
${ }^{2}$ See, for example, the speech by Mark McClellen, then Commissioner of the U.S. FDA, before the First International Colloquium on Generic Medicine. September 25, 2003, Cancun, Mexico. Available at http://www.fda.gov/oc/speeches/2003/genericdrug0925.html (accessed 12/28/03). Most recently, the U.S. insisted that reforms to Australia's domestic price and reimbursement system be a part of the AUS Free Trade Agreement (see www.aph.gov.au/Senate/committee/freetrade_ctte for details and discussion. Accessed 1/24/05). Suggesting a future agenda, see "Ten Questions," Pfizer Annual Review 2004: "We believe Americans carry an unfair share of the global cost of biomedical research. We think that's a serious issue that should be near the top of the global trade agenda."
} 
important effect. While patents indeed make local markets more attractive, they also convey control over launch decisions to multinational firms with global interests. ${ }^{4}$ Multinationals may delay or even avoid launching drugs in lower-priced countries because they are concerned about the implications for pricing in other markets. If they hesitate, and patent rights block otherwise willing local entrants, then strong patent rights may actually reduce product entry.

Although the pricing of patented pharmaceuticals has attracted a great deal of attention recently, the question of whether new drugs are marketed at all, remarkably, has not. ${ }^{5}$ This is significant given that less than one-half of the new pharmaceutical molecules marketed worldwide are sold in any given country - whether rich or poor. Even those drugs that are eventually marketed in one country frequently appear on pharmacy shelves only six or seven years after becoming available to consumers elsewhere. ${ }^{6}$ Both price regulation and intellectual property rights influence these outcomes. The CEO of Pfizer, Hank McKinnell, frankly acknowledged this point some years ago when he threatened that the company would withhold new treatments from France unless the government allowed higher drug prices (Financial Times, December 10, 2001).

When considering the effect of patent rights it is important to distinguish two main types: those that protect of methods of manufacture ("process patents") and those that protect

3 Local fixed costs include obtaining marketing approval from the country regulatory authority and educating doctors and patient groups about the drug's benefits. These costs can be sizeable, particularly for the first entrant.

${ }^{4}$ While in principle smaller local firms could develop new drugs, in fact multinationals hold almost all product patents. Some $86 \%$ of the applications for product patents in India in 1995 were submitted by inventors with a non-Indian address (CDRI, 1996) and in most developing countries the share is far higher. As firms based in developing countries also begin to invest in the development and patenting of new products they will have the same global marketing incentives and constraints faced by the current multinationals.

${ }^{5}$ Although when Gilead Sciences recently offered to expand to 95 the number of countries eligible to receive its key anti-retroviral drug "at cost", the offer was called "disingenuous" by the NGO Doctors without Borders because the firm has been supplying only 22 of the original 68 eligible countries. San Francisco Chronicle, March 18, 2005. 
pharmaceutical products ("product patents"). ${ }^{7}$ Process patents are relatively weak. While one firm's patents on methods for producing a molecule might give it a monopoly for a time, a second firm can legally devise (and patent) a new method and come into the market. Indeed, countries have purposefully chosen a "process-only" patent regime for pharmaceutical innovations in order to foster a domestic industry based on inventing around originators' manufacturing processes. $^{8}$ Although relatively weak, process patents may nevertheless encourage product entry by slowing down the arrival of competitors, allowing firms to cover fixed entry costs.

The ambiguity arises with product patents because these concentrate control in the hands of a single innovating firm. In the debate preceding the TRIPS Agreement it was argued that countries refusing to grant product patents were failing to get many newer drugs precisely because of the threat of follow-on imitative competition. If innovator firms could be assured of a local monopoly, it was suggested, they would find it attractive to launch more products. In the presence of externalities, however, this argument is no longer obvious.

Several mechanisms can generate international pricing externalities. Some developed country price regulators explicitly use cross-country comparisons to establish ceiling prices. U.K. drug prices, for example, are used as an international reference by regulators in Austria, Canada, Greece, Ireland, Italy, Luxembourg, Netherlands and Portugal (Bloom and van Reneen, 1998; see also Jacobzone 2000). Physical arbitrage across country borders can also erode prices in higher-priced markets. Arbitrage is legal among E.U. member countries, which pushes prices

\footnotetext{
${ }^{6}$ A "drug" refers to a chemical entity in any of its presentations - e.g. tablets, capsules, liquid.

${ }^{7}$ Some countries also give additional protection to new formulations and new uses of existing products.

8 India's rejection of its adopted colonial British patent code in 1972 in favor of a system allowing only short (5-7 year) process patents for drugs provides an example. With only process patents available, the multinational subsidiary Glaxo India faced several local competitors from the first day that it marketed its
} 
in the direction of uniformity although it has not resulted in a single price across markets (Kanavos, et. al., 2004; Ganslandt and Maskus, 2004). Arbitrage between most countries is illegal. Nevertheless there are concerns about black market movements, with occasional highprofile stories involving developing countries and a soaring trade between the U.S. and Canada. ${ }^{9}$

The behavior of political interest groups can also push prices toward uniformity. Consumers forcefully object to paying prices that are higher than those they see being charged to consumers elsewhere, giving firms and their regulators reason to fear a political backlash if obviously different prices are in place. A growing literature examines how firms may distort behavior to avoid the imposition of regulation or soften its effect. Glazer and McMillan (1990), for example, model pricing by a monopolist where the firm may choose to forestall regulation by setting a price closer to that desired by the regulator. Erfle and McMillan (1990) find that oil firms limited their price increases during the 1979 oil crisis. Price restraint was more pronounced on more visible fuels like home heating oil and more likely among large and visible firms. Ellison and Wolfram (2004) show that pharmaceutical firms acted collectively to restrain price increases during a period of intensive political discussion of health care reform in the U.S. Firms identified as particularly vulnerable to regulation were more likely to engage in price restraint and lobbying. Examining the stock prices of credit card firms, Stango (2003) finds that announced rate cuts were less damaging to returns when the announcements followed a regulatory threat. Again this result was more pronounced for politically visible firms. ${ }^{10}$

blockbuster drug ranitadine (Zantac); while Cipla was manufacturing a version of the Pfizer drug Viagra shortly after the drug's global launch (Wall Street Journal, July 10, 1998).

9 For example, "HIV Drugs For Africa Diverted to Europe," The Washington Post, October, 2002; "Europeans Investigate Resale of AIDS Drugs," New York Times, October 29, 2002.

${ }^{10}$ Behavior beyond pricing may also be affected. For example Maxwell, Lyon, and Hackett (2000) examine firm efforts to deter consumer mobilization, and thereby government-imposed regulation, by voluntarily limiting their pollution output. 
Identifying the precise mechanisms generating pricing externalities across markets is not the goal of this paper. Rather, the concern here is whether product patents can reduce access to new drugs by making firms that care about externalities - whatever the source - more important players. Whether access is, in fact, limited is also a key question for interpreting the welfare implication of firms' inability to fully price discriminate across countries. ${ }^{11}$

Two examples of firm behavior in this environment are instructive. In the late 1980s, Bayer chose not to introduce its new antibiotic ciprofloxacin in India. To do so it would have needed to price the product very low to be competitive in that market, at a time when the firm was negotiating prices in its more important markets. Instead, ciprofloxacin was introduced in India three years after its world launch by the Indian firm Ranbaxy. However, eight years after the drug's global launch and long after the entrance of a multitude of local producers, Bayer finally entered the Indian market (interview with Bayer executive, India, 1997). More recently, GlaxoSmithKline and Pfizer have cut back supplies of their products to Canada to prevent drugs from leaving for the United States - where they damage the higher prices that the firms enjoy in that country. ${ }^{12}$ In both of these situations the multinationals found it profitable to engage in a local market at a low price. Their reluctance to do so clearly stemmed from the potential implications for their profits in other markets. What is particularly notable in the story of

\footnotetext{
${ }^{11}$ Maleug and Schwartz (1994) show that uniform pricing by a monopolist yields lower global welfare than third-degree price discrimination when demand dispersion is such that many markets are left unserved under uniform pricing. See also Scherer and Watal (2002). This result is accentuated if one allows for global equity concerns and differences in the marginal utility of income across consumers (See Jack and Lanjouw, 2005, where they apply many-person Ramsey pricing to the problem of global pharmaceutical pricing.)

${ }^{12}$ Wall Street Journal, January 22, 2003; "Pfizer Cuts Supplies to Canadian Drugstores," The Washington Post, April 5, 2005.
} 
ciprofloxacin is the further suggestion that pricing externalities may become less acute later in the product lifecycle. ${ }^{13}$

Given the considerations raised here, one would expect to see three types of entry into poorer country markets. Firms interested in producing only for the local or regional market should be willing to enter at any time, assuming that expected returns in the local market at least cover the fixed costs of entry. Multinationals might enter poorer markets quickly in situations where they can set a price that is close to their target price in the major markets. Sales would then be limited to the local elite. Finally, one might see multinationals waiting for some time after the global launch of a new product, and then entering developing country markets with a low price that allowed them to capture market share. Which of these strategies are feasible and likely will be influenced by price regulation and the intellectual property regime.

To date there has been little analysis of the determinants of international drug launches. Danzon, Wang and Wang (2005) examine launch data from 25 major markets for the years 19941998, and a selected sample of 85 new chemical entities (NCE). They are specifically concerned with the effects of price regulation. Rather than trying to summarize differences in price control systems directly, they use the price for a standard unit in a drug's therapy class in an earlier year as indicator of the intensity of regulation. A similar variable is constructed for expected market size. Both higher prices and larger markets are found to have a significantly positive effect on the likelihood and speed of launch.

Kyle (2004a and 2004b) analyzes 21 OECD countries and much larger set of drug launches, including 1577 molecules developed during the period 1980-2002. She focuses primarily on how firm characteristics affect launch timing and finds, for example, that domestic

\footnotetext{
${ }^{13}$ One candidate explanation is the fact that controlled prices set in high-income countries in the early entry years are typically not renegotiated over time (Jacobzone, 2000).
} 
firms have a 5 times higher probability of launching at home (with domestic status most important in Japan and Italy). A dummy for price regulation has a significantly negative effect and she finds that firms are less likely to follow launch in a low-price country with launch in a high-price country.

None of these papers consider intellectual property (IP) as a determinant of marketing decisions. McCalman (2004) provides an econometric analysis of how intellectual property might influence launch decisions - of American Hollywood movies. His data are from 1997-99 covering 37 countries, and he estimates hazard models for the effect of IP strength on the speed of film launches across countries. He finds a non-monotonic relationship with moderate IP associated with the most rapid diffusion. There is, in his context however, no scope for pricing spillovers across countries.

This paper analyzes launch patterns across a very large sample of 68 countries over the period 1982-2002. The paper provides descriptive statistics; and probit and hazard analyses of the likelihood and speed of launch. Explanatory variables include those related to the attractiveness of markets and local technical capacity. Those of primary interest are newly constructed policy variables for the availability and strength of patent protection and the stringency of price control. This is the first analysis of pharmaceutical launch patterns that includes developing countries. Their experience is of independent interest and provides more variation in the policy variables than is found among OECD members.

\section{The Timing of Drug Approvals and Patent Protection}

To understand how market entry relates to price regulation and the patent system it helps to have in mind a clear idea of timing. Figure 1 illustrates with a stylized example. We assume 
that there are two countries, the United States and a lower-income country called "Other". An innovator firm discovers a promising new molecule and patents it in the United States. The top half of the first timeline corresponds to this patent, with time zero being the date at which the U.S. patent application was made. Following application it typically takes about 1.5 years before a patent is granted (King, 2003). Until recent harmonization to the 20 year standard agreed under TRIPS, the United States had a statutory patent term of 17 years from the grant of the patent. This would give a total expected patent term of 18.5 years. In addition, however, the U.S. has a provision to allow for an extension of the patent term on pharmaceutical products to compensate for time spent in the testing and regulatory review process. ${ }^{14}$ The average extension during the period of our data was about 2 years (Grabowski and Vernon, 2000), pushing the expected expiration date out to 20.5 years after application as indicated.

After having applied for a patent on its new molecule in the United States, the innovator firm has up to 12 months to submit its corresponding patent applications in other countries. ${ }^{15}$ The bottom half of the patent timeline tracks the firm's product patent in "Other", assuming that product patents are available there. Again time zero is the date when that the application is submitted and it falls one year later than for the U.S patent.

Applications to protect manufacturing processes may be, and often are, submitted some time after initial product patent applications. Thus there may be additional patents associated with the new product. These patents would have timelines shifted to the right of the one shown,

\footnotetext{
${ }^{14}$ Introducing the option for a patent extension was one part of a larger political agreement that also allowed generic firms to enter the U.S. market by showing equivalence to an existing approved product and without repeating full clinical trials (the Drug Price Competition and Patent Term Restoration Act or "Hatch-Waxman Act" of 1984).

15 This period may be extended via a PCT application, but most subsequent applications are made a year later almost to the day (based on data from the Thomson Derwent World Patent Index).
} 
with expiration dates further out in time. An innovative firm can effectively extend the number of years that it controls the marketing of a product if it can successfully patent all commercially feasible methods to manufacture it. ${ }^{16}$

Typically a pharmaceutical product patent application is made early in the R\&D process. Thus, in the years following its U.S. patent application the innovator firm develops the potential product. If this stage is successful, the firm develops a dossier that describes the drug's quality and characteristics and contains reports on tests of safety and efficacy. The completed dossier is submitted to the U.S. Food and Drug Administration (U.S. FDA) for marketing approval. During the mid-1900's, the regulatory approval process took, on average, about 1.5 years (various sources in the policy references). Although there was considerable variation, during our period of analysis the average total time elapsed to final approval in the United States was about 9 years after the initial patent application (based on the 18.5 year pre-extension term and Figures 3 and 4 in Grabowski and Vernon, 2000). Following approval, drugs enter the market directly, as indicated on the figure. ${ }^{17}$

The date of entry into the U.S. market represents the first global launch of the product in this illustration. The first global launch in any market is time zero in the econometric analysis and starts the lower "launch lag" timeline in the figure.

\footnotetext{
${ }^{16}$ This may difficult. For example, in 1991 Eli Lilly was losing molecule protection in the U.S. on its major drug cefaclor, but anticipated extending the protection of its drug on the basis of a large number of U.S. process patents. At the same time, however, the Indian firm Ranbaxy found an unpatented manufacturing process that undermined this strategy. In the words of a Ranbaxy executive, " 56 processes were under patent (by Lilly in the U.S.) and we found the $57^{\text {thl" }}$ (personal interview, 1997).

${ }^{17}$ Competitiveness and Performance Indicators 2001. Pharmaceutical Industry Competitiveness Taskforce. Available at http://www.advisorybodies.doh.gov.uk/pictf/cpi2001.pdf (accessed $1 / 3 / 05)$.
} 
When the product enters the market in "Other" depends upon the firm attempting to market it. Most developing countries will give regulatory approval to a drug largely on the basis of a product's acceptance by the U.S. FDA or similar E.U. authority. Thus our originator firm could submit its dossier when it makes its submission to the U.S. FDA and expect approval at more or less the same time. A generic applicant, on the other hand, would need to show equivalence to the already approved product, and this might delay its submission. On average the approvals process in developing countries during the mid-1990s was also on the order of 1.5 years (policy references). Thus, assuming a firm makes the effort to enter quickly, we indicate approval in "Other" as one to 1.5 years after the U.S. approval date.

In most countries, marketing approval is followed by a period during which the firm negotiates the conditions of entry with a government body charged with regulating reimbursement and pricing. This process can naturally vary in length depending on the stances taken by the negotiating parties and the procedural framework. A study of developed country markets found that the average additional delay due to price negotiations was relatively short $-\mathrm{a}$ few up to about ten months. ${ }^{18}$ Assuming that negotiations might be somewhat more protracted in developing countries, we indicate market entry in "Other" at year 10. This implies entry two years after the first global launch, as shown on the bottom timeline.

What these timelines highlight is that the effective life of a patent - the number of years during which a patent protects a product that is out in the market generating revenue - is typically nine or ten years shorter than the statutory term of the patent. We refer to this figure when interpreting the results below.

18 ibid. Consultant and industry sources cited in Danzon et al (2003) suggest somewhat longer delays due to price negotiation. 


\section{The Drug Launch Data}

The launch data are drawn primarily from the December 2002 "LifeCycle: Drug Launches" database constructed by the private vendor IMS Health. The database identifies the month and year that a product first has retail sales in a given country, and indicates which entries represent first world launches of new chemical entities (NCE) ${ }^{19}$ For each product launched, it gives the tradename, the Anatomical Therapeutic Classification (ATC) code, active ingredient, composition, and firm making the launch. Coverage includes entry during the 21 years 19822002 in the retail sector and, for some countries, the hospital sector also. The Indian market was not covered by IMS during this period so we incorporate similar information obtained from the Indian market research company, ORG-MARG. The Indian data cover a partial, but broad, set of therapeutic classes - including launches of all antibiotics, ulcer and cancer drugs - and includes all products in those classes launched in the Indian market during the period 1986-98. The combined dataset covers 68 countries or country groups, $60 \%$ of which have at least twenty years of information. ${ }^{20}$

Because the brand names given to the same product change across countries, and may include generics, common products must be linked across countries on the basis of active

${ }^{19}$ In some cases the same chemical was indicated as being 'new' more than once, or was identified as 'new' at a country launch later than the first launch in the world. In these cases the first appearance is taken as the global launch date.

${ }^{20}$ French West Africa (Benin, Cameroon, Congo, Cote d'Ivoire, Gabon, Guinea, Senegal) and Central America (Costa Rica, El Salvador, Guatamala, Honduras, Panama) are aggregated by IMS because they are very small markets. During the period 1982-1992 we have data for "West Germany", which overlaps with data for "Germany" beginning in 1989. Inspection of the entries for these two "different" countries during the overlap period reveals some drugs released in both countries and others in one or the other. These observations are treated as a single market during the overlap period. For the 1982-1988 period, IMS also reports launch information for "Malaysia", "Singapore", and a "Malaysia, Singapore" hybrid. Drugs released as "Malaysia, Singapore" are treated as having been launched in each country and the observations are replicated. 
ingredients. Although (active) "ingredient" is a variable field, it is incomplete in the IMS data, with a sizable share of the observations missing active ingredient information altogether. ${ }^{21} \mathrm{We}$ assume that drugs having a tradename that is the same as one of the NCE chemicals are generics and assign to them their tradename chemical as an ingredient. After having made this change, about $10 \%$ of the observations were left with missing ingredient information. The share of launches missing this key linking variable differs considerably across countries but is not obviously related to language or income. For example, $18 \%$ of U.S. launches are missing ingredient but only $9 \%$ of Japanese and Swedish launches.

The IMS data contains a field "Composition" which includes both active and inert ingredients. Two-thirds of the observations with missing information in the ingredient field had information in the composition field. This field revealed that many of products missing information are not likely to be NCEs (for example, "charcoal", "calf blood extract", "acne acid detergent"). While the ingredient field typically had chemicals listed in the common chemical nomenclature, those listed in the composition field were more often in the language of the country of release (for example, "pirodoxina chlorhidrato", "rosskastanien samen-trokenextrakt", "prodotto a base di aglio"). To avoid introducing new noise and probably a bias associated with language, no attempt was made to use the composition field to identify active ingredients where they were missing. Observations that do not have identified ingredients are dropped from the analysis except in Table 4 below.

To improve the links between common products for those observations that do have identified ingredients, we constructed a set of chemical "equivalent names" for each of the

${ }^{21}$ There was considerable improvement in reporting over time: about 1/3 of the 1980's launch observations are missing ingredient, while the data are complete for launches in the last five years. 
NCEs. Most of the equivalent names came from a search of an online chemical database called ChemID Plus. $^{22}$ This yielded 5,374 synonyms. In addition, we found the original tradename under which each NCE was first launched, identified all products launched under each of those tradenames, and the products' ingredients. Whenever a given NCE tradename had different ingredients listed for products in different countries, these were scrutinized to find different spellings due to language or misspellings. This resulted in a further 61 equivalent names to use for matching.

Drugs assigned to an ATC code beginning with "T" (diagnostic agents and testing devices) or "V" (various, including dietetic supplements and similar products) were dropped.

Appendix Table A1 gives an example of a launch pattern for the pharmaceutical ciprofloxacin. Countries are ordered by date of market entry. Ciprofloxacin was first marketed in the Philippines in October of 1986, so this date is time zero. The number of months between the date of the first global launch of a drug and its launch in a given country is the launch lag. These are given in the last column of the table.

\section{Description of Global Launch Patterns}

Table 1 gives the number of NCE's with a first appearance (global launch date) in each year. The first column indicates the number of new "blockbusters". These are drugs that were found among the top 200 in terms of world revenue in 1998 or 2003, or among the top 100 U.S. revenue earners in 1995 and 1993 (Med Ad News, various issues). The second column includes all drugs. There was an increase in the number of new chemical entities launched in the mid1980's, with some fall off in the numbers in the early 2000's (perhaps due in part to data

\footnotetext{
${ }^{22}$ at http://chem.sis.nlm.nih.gov/chemidplus/cmplxqry.html (accessed March, 2003).
} 
processing delays). On the whole, however, the number of NCE's appearing each year was fairly similar over the period.

There were 836 new pharmaceuticals first marketed during the period $1982-2002$. Table 2 indicates the location of these first launches. The table includes countries having at least one first launch, ordered by income class. ${ }^{23}$ To give an accurate picture of the actual importance of countries as a location of first launch, these figures must be adjusted to account for the incomplete coverage of some countries over the period (see column 2). For example, Russia appears as the location of first launch only twice, but this is due in part to our having only eight years of information. Adjusted shares are in column 3. They are constructed as follows. Let $d_{j t}$ be the observed number of first launches in country $j$ in year $t$ and $D_{t}$ the observed first launches in year $t$ worldwide. Let $s_{j 0}$ be an estimate of country $j$ 's share of first launches based on data from the seven-year period 1995-2001 when information was available for all countries. For the remaining years, first estimate the true number of first launches as $D_{t}^{*}=\frac{D_{t}}{\sum_{j \in J_{t}} s_{j 0}}$, where $J_{t}$ is the set of all countries having data in year $t$. Then, for each country $j \in J_{t}$ construct estimates of the country's annual shares as $s_{j t}=\frac{d_{j t}}{D_{t}^{*}}$. Each country's adjusted share of first launches over the entire period is a weighted average of $s_{j 0}$ (the share over 1995-2001) and the other annual estimates $s_{j t}$ available for that country.

Two points stand out in this table. First, firms almost invariably launch products first in rich country markets. Second, a very large share of all drugs is launched first in Japan (and only there - see below). 
Figure 2 gives an idea of the number of countries that an NCE typically reaches. It is based only on the 300 NCEs with global launch dates early in the period (1982-1988) to avoid truncation. We see that just a very few drugs from that time period were launched worldwide. The mean number of countries is 20 , the median is 9 , and almost $20 \%$ of new drugs are marketed in just a single country. Of the 54 single-market drugs represented in this figure, 23 were sold only in Japan, 13 only in Italy, with the rest scattered across countries. Japan is clearly distinctive - it is the location of $24 \%$ of all drug launches, but $43 \%$ of those marketed in a single country. From 1995 there was a marked increase in the number of countries reached within a short span after global launch, so it is likely that today the distribution shown in Figure 2 has shifted rightward.

Table 3 indicates how long it takes for a drug to become available to a country's consumers. Calculations in this table are restricted to the 122 NCEs first launched 1986-92 and assigned to therapy classes for which the Indian data are available. There is some truncation for drugs entering after a long delay because the data end at 2002, but each NCE has at least 120 months of information. It is evident that lags tend to lengthen as one goes down the income rankings. The group summary at the bottom of the table shows that differences are most pronounced between the high-income countries and the rest. ${ }^{24}$ However, there is also clearly a great deal of variation across individual countries: median launch lags range from months (Japan, Switzerland) to over eight years (Latvia, Lebanon). There is also considerable variation across products within countries: For example, the difference between the $10^{\text {th }}$ and $90^{\text {th }}$ percentile of the

${ }^{23}$ The income classes follow those in the World Bank 2002 World Development Indicators Report. The ranges for GNI per capita measured in 1999 U.S. dollars are: Low $\leq \$ 755<$ Lower $\leq \$ 2995<$ Middle $\leq \$ 9265<$ High . 
lag distribution is over 10 years in Morocco and Peru and over 7 years in some of the OECD countries.

To avoid differing degrees of truncation across years, Table 4 restricts attention to launches that occur within 10 years of the first global launch of each NCE. The ten-year span includes most market entry, as shown in the previous table. Table 4 includes the 91 "blockbuster" and 462 total drugs in all therapy classes first launched during 1982-92 (so India is dropped). The first column, on the left side of the table gives the percentage of all drugs that was eventually launched in the row country at any point within a ten year lag. The second column gives the same statistic but grossed up as though products missing ingredient information are, in fact, NCE products. As discussed in the previous section, this is clearly not the case so these values would be generous upper bounds. The third column gives the percentage of blockbusters eventually launched in each country.

Considering the first column, the percentage of drugs launched within a ten year lag ranges from lows of 19\% and 22\% (Egypt, Malaysia) to highs of $49 \%$ and 53\% (Italy, Japan). Thus, no consumers anywhere have access to more than about one-half of the new pharmaceuticals that enter the world market. The mean (unweighted) percentage is $34.8 \%$ for the high-income countries, and $29.9 \%$ and $28.4 \%$ for the middle- and low-income countries, respectively. As expected, "blockbuster" drugs that experience high sales revenues in the developed world are also launched more frequently in the poorer countries than drugs overall, although in no country is the rate for even this more select group close to $100 \%$. The fact that

${ }^{24}$ The difference for high income countries is not driven by the fact that Japan has a large number of unique drugs. Dropping Japan lowers the average number of drugs to 40 and increases the median lag to 28 months. 
drugs are not launched more widely can be due to the availability of substitutes, differences in disease patterns across countries, and rejection by some local regulatory authorities.

The remaining columns of Table 4 give the cumulative distribution of drug launches at different lags from one year to nine years. Thus the column headed " 3 " indicates the percentage of all NCE launched within ten years in a given row country that arrived in that market within three years. Countries are listed by income group and, looking down this column, we again see that drugs are more likely to be launched within three years in the richer countries than in the poorer countries. This is highlighted in Figure 3, which shows unweighted averages for each income group. However, the pattern is not strong. Israel, at $27 \%$, for example, has a smaller share on the market this quickly than either the Philippines or Thailand (44\% and $41 \%$ respectively). Again we see the large range of experience overall. Germany has $75 \%$ of its drugs on the market within three years of the global launch, Saudi Arabia just $16 \%$.

Most global market entry is done by the "first" firm, defined as the firm that makes the first global launch of an NCE in a high-income country, or any country for the few NCE launched exclusively in the poorer countries. This firm almost surely holds most of the patents associated with an NCE and is typically a multinational. A smaller share is done by "other" firms - which may in many cases be entry done under license as part of a marketing arrangement and thus effectively controlled by the first firm (the data do not allow one to distinguish). "Other" firms may also be multinationals.

Shares for the low- and middle-income countries are shown in Table 5, broken down by type of patent regime. Moving from left to right, a stronger patent regime is associated with more of the drug launch in a country being done by the first firm. Overall, two-thirds of all drug launches and three-quarters of blockbuster launches are done by the first firm. These firms are 
responsible for about $80 \%$ of all new drug launches in the poorer countries that occur within the first 3 years. That these firms tend to enter markets more rapidly is also clear in Figure 4, which shows the timing of drug entry in high or lower-income countries conditional on launch being done by the "first" or "other" firm.

To summarize the descriptive statistics:

- Only $20 \%$ to $50 \%$ of all drugs launched globally are on the market in any country after 10 years. This rises to $60 \%$ to $85 \%$ for high revenue blockbuster drugs.

- Across countries there is considerable variation in how quickly drugs arrive on the market given that they are ever launched.

- There is some indication that countries with higher GDP per capita tend to obtain new drugs more quickly, but the pattern is not strong.

- Within any given country there is also considerable variation in how quickly individual drugs are launched - ranging from a few months to over a decade.

- On average, the firm associated with the first marketing of a new chemical entity is responsible for most of the subsequent launches of that product and tends to enter drugs more quickly than other firms launching the same product.

\section{The Explanatory Variables}

Annual series were constructed to describe each of the main policy areas:

Intellectual Property Protection: These include indicator variables for the availability of patents on innovative methods of manufacture for pharmaceuticals (process patents), and on new pharmaceutical compounds (product patents). Historically, countries have offered either no 
protection in the area of pharmaceuticals, process patents only, or both process and product patents. The data include the statuary term of each form of protection, and information about whether a country allows for an extension to the patent term to compensate for time spent in the marketing approvals process.

How a country interprets and enforces its patent laws clearly affects how meaningful any patent "rights" are to their owners. Unfortunately this is a difficult characteristic to capture in data. We use one variable, "strong," falling between 0 and 1 , which takes on a higher value as a country limits how patent rights can be curtailed. Specifically, it is the average of non-missing values for three other 0/1 indicators: the first equals one if a country will not impose compulsory licensing until three years after patent grant; the second equals one if the country has no formal obligation to "work" a patent (supply the market); and the third equals one if the country does not revoke patents for failing to work if there is such a requirement. This variable was devised by Walter Park, who provided the data required for its construction for most countries for each five years beginning in 1980 (see Ginarte and Park, 1997, for details). For missing countries, his data were supplemented assuming current values throughout the period based on the legal texts referenced below. A similar variable composed of enforcement-related indicators was not found to have any explanatory power and therefore was not included in the estimations.

Price Control: There is bewildering variety in the ways in which different countries approach the control of pharmaceutical prices. We consider systems of explicit price regulation and summarize the variation across countries with two dummy variables - one for the existence of "some" price control regulation and the second for "extensive" price control. A price regime is label "extensive" if all drugs are regulated, rather than just a subset of the market, or if a 
country's price regulation is identified by commentators as being particularly rigorous. The set of reports consulted in making this determination is given in the policy section of the references.

The legal and regulatory policies of a country result from some process, and this makes endogeneity an obvious concern when trying to understand the effects of any policy regime. In our case, one might expect firms to lobby hardest to obtain strong patent protection in countries viewed as attractive markets for entry, potentially creating a positive bias in estimated relationships. ${ }^{25}$ However, a consideration of history suggests that substantive within-country changes in the patent law can reasonably be treated as exogenous for our purpose - certainly in their timing. Such changes tend to be forced by the rules of entry into new political groups (e.g., Portugal and Spain joining the EU in 1992); by newly negotiated standards created at an international level (e.g., many poor countries and TRIPS, Mexico and NAFTA); or a vulnerability to trade pressure and the political dynamic of bilateral negotiations (Korea, Brazil, and Jordan in the 1980s and 1990s). (See Sell, 2003.) The link to the dynamic of trade negotiations is reflected in comments by the body that advises the U.S. Congress and administration on IPR and trade, the Industry Functional Advisory Committee on IPR for Trade Matters (IFAC-3), in its reports to the US Trade Representative:

CAFTA (the Central American Free Trade Agreement) "mirrors, as closely as possible, the Singapore and Chile FTAs in order to establish clear precedents in most key areas of intellectual property protection for future FTA negotiations."

And

${ }^{25}$ And lobby they do. For a candid discussion see historical issues of the PhRMA annual report. 
"IFAC-3 is particularly gratified that....with high-level agreements with both small developing countries in the CAFTA and a strong and mature developed country like Australia, it will prove much easier to convince future FTA countries that strong intellectual property protection is in the interests of all countries regardless of their economic circumstances." (Italics mine). ${ }^{26}$

Price regulation is more likely to be endogenous. While patent laws change only rarely, and then in fairly specific and major ways, governments may more flexibly adjust price controls. In particular, a government might be willing to limit the scope or intensity of an existing system even where it would not dismantle it altogether. Weaker regulation might be associated with pressure from an industry with an eye on entry for other reasons. There are, however, strong countervailing forces that limit industry influence, such as budgetary pressures and vigorous lobbying by patient groups and the retired elderly.

Control Variables: To mitigate potential endogeneity concerns and remove noise, we construct controls for other characteristics that one might expect to influence pharmaceutical marketing. Some of these control variables are of independent interest. Given our hypothesis that multinationals might be reluctant to launch in poor countries when they face price competition, and that local firms could be an alternative source of new drug entry, the presence of a competitive local industry should be relevant. The finding in Section 3 that innovator firms are responsible for most global marketing suggests that the price effect of local competition

\footnotetext{
${ }^{26}$ Industry Functional Advisory Committee on IPR for Trade Matters (IFAC-3) in reports to the USTR: $\quad$ http://www.ustr.gov/assets/Trade_Agreements/Bilateral/CAFTADR/CAFTA_Reports/asset_upload_file571_5945.pdf and http://www.ustr.gov/assets/Trade_Agreements/Bilateral/Morocco_FTA/Reports/asset_upload_fil e164_3139.pdf
} 
could be particularly important. Country R\&D expenditure (in all areas) as a share of GDP is included as a regressor to capture local technical capacity and thus the potential for imitative competition. High tariffs in a country may also make entry less attractive to multinationals that would anticipate importing supplies from centralized production facilities. High-income countries have zero rates on pharmaceuticals, but in the poorer countries there is considerable variation, with rates as high as $35 \% .{ }^{27}$

Differences in market opportunities are captured by the demographic indicators population size and the percentages of the population aged 0-14, 15-64, 65+ years. Economic variables include the level of GDP per capita. The Gini coefficient of inequality, and asset ownership, provide some measure of differences in income distributions. We also control for the share of health expenditure in GDP, and the share of health expenditure that is private, and the share of doctors in the population.

Characteristics of the regulatory process can also influence market entry. Health authorities differ in their standards and some may reject a new drug even when it is on the market elsewhere. Delays in the marketing approvals process can take the speed of drug launch at least partially out of the hands of firms. ${ }^{28}$ The observed timing of market entry reflects some combination of the decisions of firms and the complexity and efficiency of a country's regulatory process. Thus, the estimations include other elements of government policy that might directly

(both accessed 12/06/04).

27 The data used here were drawn from the UNCTAD database and kindly supplied by Adrian Otten. See European Union (2003) in the policy references for a description of these regulations.

${ }^{28}$ Firms are able to influence how quickly a given drug moves through the approvals process. They can work with more institutions and offer greater compensation to participants in order to rapidly reach required sample sizes for clinical trials. They can direct more resources to interacting with the authorities during the approvals process. Dranove and Meltzer (1994) provide evidence from the United States that firm work harder to speed the approval of drugs that are later successful in the market. 
affect or proxy for other conditions that influence entry timing, beyond our key variables of interest. These include whether a country has adopted an essential drug list, standard treatment guidelines or a national formulary. For E.U. members we include an indicator for the 1995 establishment of the European Medicines Evaluation Agency. This agency offers a centralized, and thus potentially more rapid, approvals procedure within the European Union.

Many of the explanatory variables are available annually and others are in one or several cross-sections. All variables used in the estimations presented below are defined in Appendix Table A2 with summary statistics in Table A3.

\section{Econometric Analyses of Launch Determinants}

This section describes the probit and hazard model estimations used to analyze the probability and speed of drug launch. Results are discussed in the following section.

All estimations are done separately for the high-income countries and for a combined low-and middle-income grouping. We consider four different subsets of the NCE in the data. The base estimations include all drugs. However, some drugs launched in one location fail to reach other county markets because they do not meet those countries' local health standards for safety or efficacy. We want to distinguish between firm's decisions not to launch, and a failure to fulfill marketing requirements. Thus, for the high-income countries we also estimate the models on a "high quality" subset of NCEs, defined as those that obtain marketing approval and are launched in either the U.S. or the U.K within 2 years. This follows Danzon, et. al. (2005), who 
argue that these two countries have the most stringent regulation and that therefore approval for their markets implies a minimum quality standard. ${ }^{29}$

For the low- and middle-income group we focus on the set of "blockbuster" drugs - those of greatest commercial importance as measured by sales revenue. The group includes drugs of great medical importance and also some major "lifestyle" drugs. We examine the launch of blockbuster drugs in the low and middle-income group only, because one could expect drugs in this group to be launched extensively in the rich countries (although see the third column of Table 4.)

Finally, when examining launch in the lower-income group we consider separately NCE in therapy classes that have sales relatively more concentrated in developing countries: class A (alimentary tract and metabolism) and class $\mathbf{J}$ (systemic anti-infectives). The sales of drugs in class $\mathrm{A}$ and $\mathrm{J}$ were $23.6 \%$ and $23.0 \%$ of all sales in India in 2000 , while only $10.4 \%$ and $18.1 \%$ of the NCE in our data fell in these therapy classes (sales figures from Chaudhuri, et. al., 2004). Firms might have stronger incentive to enter poorer markets with products in these classes. ${ }^{30}$

Tables 6-8 and Tables 10-11 contain the estimation results for probit models of the probability that a new drug is launched in a given country within either two years or ten years of the drug's first appearance in the global market. Observations are at the level of a country/NCE and the dependent variable takes on the value one if the NCE was marketed within the indicated

\footnotetext{
${ }^{29}$ Unlike Danzon, et. al., we drop the U.S. and the U.K. as launch countries when analyzing this subset since their launch probabilities are biased upwards by construction. Another way to approach the quality issue is to restrict attention to drugs known to satisfy a given country's standards because they are observed entering its market within ten years, and analyze the probability that those drugs are launched within two years (analogous to Table 4). Unreported estimates on this subset support the results discussed below.

${ }^{30}$ Virtually all drugs are also marketed in the high-income countries. Of the over four hundred NCE launched through 1992, only eight were launched exclusively in the low- and middleincome countries and only one of these in more than a single country.
} 
period of time. A 24-month lag is below the median lag for high-income countries, and below the $10^{\text {th }}$ percentile for low- and middle-income countries (see Table 3). Thus, product entry within this timeframe represents relatively rapid launch, particularly in the poorer countries. As discussed in Section I, the procedural steps associated with market entry should not typically require a delay longer than two years, particularly for the originator firm (see Figure 1). Thus, if a launch fails to happen within two years one can fairly assume that this failure involved at least some element of firm choice to delay, or that a decision was made to enter but the product was rejected by the health authority. The descriptive statistics presented above suggest that a lag of ten years is a reasonable indicator of whether a drug is "ever launched".

Table 9 contains estimation results for a log-logistic hazard model of the time path of country launches. ${ }^{31}$ The log-logistic model implies that the probability of failing to have a new drug on the market $t$ months after the global launch is

$$
S(t)=\left[1+\left(\frac{t}{\exp \{x \beta\}}\right)^{1 / \gamma}\right]^{-1} .
$$

This functional form allows for increasing and then decreasing hazards rates through the parameter $\gamma$ and was preferred over other frequently used specifications such as Cox proportional hazard or Weibull models for all subsets of the data. Comparing the empirical cumulative hazard rates and the Cox-Snell residuals revealed predicted hazards that were too high in the later years. This is reasonably explained by the fact that for each country the sample is a combination of drugs that are eventually launched - hence which are well described by the model - and those that never will be. To accommodate this unobserved heterogeneity across drugs, the estimations also allow for a multiplicative factor on individual hazards having a Gamma distribution with

${ }^{31}$ Global launches are defined as being a launch in the first month to avoid those observations being dropped. 
mean one and variance $\theta$. This standard form yields a convenient analytical expression for the likelihood function.

In all specifications, countries enter the estimation for a given NCE only if the NCE's global launch precedes the entry of the country into the database. To avoid truncation, the hazard estimations include NCE first launched 1982-2001, the probit estimations for a two-year lag include those first launched 1982-2000, while those for the ten-year lag include only NCE with first launch 1982-1992. All estimations include full sets of dummy variables for both the date of NCE first global launch and the fourteen ATC therapeutic classes. Country fixed effects are also included in some of the probit estimations - as indicated in the column headings - and in the hazard estimations. Their inclusion implies the loss of all information available from crosscountry variation in the key policy variables; but focusing on within-country changes over time has the advantage of controlling for any unobserved market characteristics that might be correlated with those variables. Appendix Table A4 indicates the countries that saw changes in their policy variables during relevant time periods. Time, therapy class, and (where included) country fixed effects are each jointly significant in all cases. Where country fixed effects are not included in the model, the estimations allow for a country random effect.

Explanatory variables are dated by the year of the first global launch. For example, if an NCE is first marketed in 1990 then it is a country's population size in the year 1990 that is considered as a determinant of drug launch in the period two or ten years after 1990. This is not obviously the right assumption - one might expect that the relevant characteristics would be those for a later period, particularly for the probability of launch within ten years. However, experimentation showed that both policy and market variables dated after the global launch (either two or four years) have weaker explanatory power in models of new product launch. It 
may be that worldwide launch decisions for a new drug are taken at the time of first marketing and do not readily respond to subsequent changes in the policy environment.

\section{The Estimation Results}

We now examine the determinants of drug launch. Coefficient estimates on the patent regime and price control variables are discussed in detail, followed by a brief discussion of other estimates.

\section{Low- and Middle-income Countries}

Results of probit estimations for the low- and middle-income countries are presented in Tables 6 through 8, with corresponding hazard model estimates in Table 9.

The type of patent protection offered by a country in this income grouping is characterized by a set of five dummy variables (see the first rows of Table 6). Information on the length of protection is collapsed into indicator variables for whether the statutory patent term is short vs. long. This distinction has explanatory power whereas the specific term length in years does not. While somewhat surprising, launch decisions are made by managers who must synthesize different types of information and it is quite plausible that the simpler breakdown is the way in which they think about country patent policies when making their choices.

The first of the five dummy variables indicates whether a country offers at least shortterm process protection for pharmaceuticals versus no protection at all (see the diagram below). For the lower-income countries "short" refers to a statutory term of 14 years or less. ${ }^{32}$ Recalling Figure 1, a term of 14 years would imply that, on average, about four years of effective protection would be conveyed by a patent on the product molecule and perhaps a few more years

32 Experimenting sequentially with cutoffs from 12 to 17 years, 14 gave the highest pseudo- $R^{2}$. 


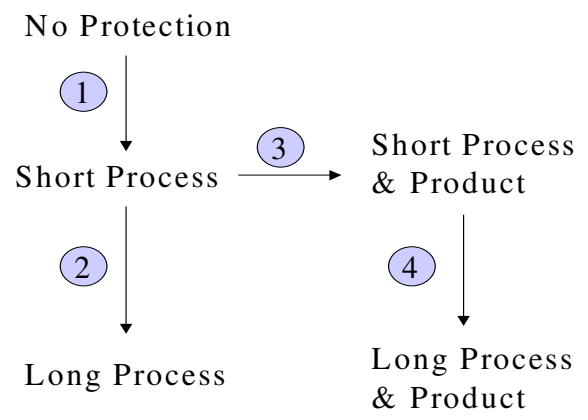

by associated process patents because of their later application dates. Of the periods in which countries in the data offered a short term of protection, in about $25 \%$ of cases the term was 14 years. In about $50 \%$ the term was 12 years, implying an average effective patent life of only a few years. In the remaining cases the term was just 7 years.

The next two variables capture the incremental effect of moving to either to long process protection ( $\geq 15$ years), or alternatively adding short product protection. The forth variable indicates the additional effect of going from short protection of both products and processes to long protection of both. (One never observes a country with short product protection and long process protection.) The final dummy variable indicates whether the country will grant an extension on product patents to compensate for marketing time lost during the approvals process.

Table 6 presents results for the full set of drugs. The first model, shown in column one, includes country fixed effects, while the second model does not. ${ }^{33}$ Because the latter

${ }^{33}$ Because there is limited variation in the policy variables - particularly when country fixed effects are included - a jackknife procedure was used to look for potential overfitting of the data. Countries were dropped in turn, the model re-estimated and the resulting coefficient estimates checked for stability. 
specification includes the Gini coefficient as a control, a number of countries are lost due to missing information.

The estimates are quite robust to the assumption of fixed or random country effects, which lends empirical support to the argument that the set of policy variables can be treated as exogeneous. As noted above, the decision whether to maintain an extensive price control system in the face of international corporate or governmental pressure is the policy choice most likely to be problematic. To test whether endogeneity in this variable might be influencing the results, we also estimate a two-stage conditional maximum likelihood version of the model in column two that includes the residual from a first-stage regression for extensive price control (Rivers and Vuong, 1988). Significant instruments in the first-stage regression include the economic orientation of the ruling executive party, its tenure in power, and the overall budget balance. ${ }^{34}$ First-stage estimates are provided in Appendix Table A5. The exogeneity of the extensive price control variable in the probit for launch is not rejected (null hypothesis that the residual coefficient is zero: $\chi^{2}(1)=0.42$, p-value $=0.52$ ). The coefficients in the launch model change little so they are not reported.

Given the historical link between changes in patent law and trade agreements, one might also be concerned that what looks like a positive role for stronger patents could be due to other changes in the trade regime facilitating market interaction. To test this, annual exports was included as a control variable in unreported estimations. Its inclusion had little effect on the estimated coefficients on the policy variables.

${ }^{34}$ Budget stress could increase the stringency of price regulation as countries that cover pharmaceuticals though general expenditure strive to control costs (for many specific incidents in the E.U., see Jacobzone, 2000). Because it could conceivably have a direct effect on the government's willingness to approve relatively expensive new drugs we also run the two-stage estimations dropping this variable. The results are the same. 
The observed probability that a drug is launched in a low- or middle-income country within two years is about 9\%. The estimates in Table 6 suggest that going from a regime with only short process patents to one with long process patents significantly encourages rapid entry. A long process patent regime still allows for possible generic entry and this appears to be important. The marginal effect is to raise the probability of launch within two years by 2-3 percentage points (or about 30\%). There is little evidence, however, that offering any form of protection to new pharmaceutical products enhances the likelihood of quick entry into these markets. The individual incremental effects of adding short and then long product protection are insignificant in both specifications, and the joint marginal effect is weakly significant only in the random effects model $(0.021+0.008$, p-value 0.08$)$.

Extensive price control clearly lowers the probability that new pharmaceuticals reach consumers quickly in lower-income countries, as expected. The predicted effect is similar in magnitude to that of the change to a longer term on process patents - in this case lowering the probability of rapid entry by some $30 \%$. That a country has an essential drugs list is also associated with a lower likelihood that new drugs are launched quickly and may indicate more focused efforts by the government to ensure that drug purchases are cost effective. Moderate price control, on the other hand, does not appear to have a significant influence on entry in these specifications.

The first two columns of Table 7 present the main results for estimates when additional variables are included in the random effects specification. The first adds a country's R\&D share and its level of tariff protection (which together lead to a sizable drop in the number of observations due to missing data). We again find that having a long process patent regime significantly encourages rapid drug launch. A new finding is that countries with a high technical 
capacity as measured by R\&D expenditure are far less likely to see new pharmaceuticals in the market quickly. Starting from no R\&D and then increasing R\&D to the mean level of one-half of one percent of GDP drops the probability of rapid launch by an estimated 13.6 percentage points. This negative effect of local capacity, however, is significantly offset if a country offers the strongest level of patent protection. Although the effect of a higher R\&D share remains negative even when interacted with strong patent protection, its marginal effect is diminished by a third (joint marginal effect $=-0.19, \mathrm{p}$-value $=0.01$, versus -0.28 ).

As in the simpler specification, extensive price control has a significant negative effect on the probability of rapid launch. Moderate regulation of prices is also found to have a negative effect now that the specification allows for its interaction with GDP per capita. The impact of having any price regulation is sizable for the poorest countries, and is only fully absent at a GDP over $\$ 11,000$, or higher than cutoff for this country group. That price regulation has a larger effect in the poorest countries may reflect firm choices. It might also result from low-income countries having less efficient regulatory procedures that slow price negotiations. There is some suggestion of the importance of variation in regulatory efficiency within the lower-income countries in the fact that the coefficient estimate on having a national formulary is significantly positive (which is not the case for the higher-income countries, see below). One would expect its direct effect to be negative, but within the lower-income country group this variable may be acting as a proxy for bureaucratic competence.

The specification shown in the second column of Table 7 includes interactions between short and long product patent variables and the indicator "Strong" that indicates limits on how patent rights can be curtailed. There is some weak evidence from these interactions that short product patents may encourage rapid entry when they are held in a legal environment more 
generally supportive of patentee rights. It may be, for example, that in such an environment the patent holder feels able to simply import product rather than go through the time consuming process of finding local producers and/or distributors to license.

The third and forth columns of Table 7 correspond to the same random effect model as in column 2 of Table 6, but for the NCE subsets indicated in the column headings. As found for all drugs, the NCE most relevant to poor countries ("LDC concentrated") are more likely to be launched quickly when a country offers only long process patent protection. In addition, for this subset of NCE there is also evidence that offering long protection on pharmaceutical products can encourage rapid entry. The incremental effect of long product protection is positive and weakly significant and the estimated coefficient on having a patent term extension provision is both significant and sizable. Results for the other policy variables are similar to those for all drugs.

The last set of estimates given in Table 7 is for the high revenue "blockbuster" drugs. For a low- and middle-income country the probability that one of these drugs is launched within two years is considerable higher than is the probability for all NCE (24\% vs. 9\%). That said, there is no evidence that offering any form of patent protection - whether long or short - speeds the arrival of the worlds' blockbuster drugs to their markets. This finding does not seem to be an artifact of the smaller sample size, since other estimations showing significant effects of the patent variables have even smaller sample sizes. Further, the other policy variables remain significant and are estimated to have a similar-sized effect on the launch of blockbusters (relative to the observed probability) as they do for other sets of NCE.

Table 8 compares results for the probability of launch within two years ("rapid") and ten years ("ever") using only NCE launched globally by 1992 in both cases so as to enable 
comparisons across a common sample of drugs. Considering first the within 2 year results, as in the full period data there is evidence that a long process patent regime - possibly supporting generic entry - is conducive to rapid drug launch. However, unlike in the full period data, in this earlier subset of NCE a long patent regime also including products - possibly encouraging entry by innovator firms - gives significant support to rapid entry. Both patent regimes offering a long period of protection are estimated to have similar-sized marginal effects: 0.086 without product patents and 0.070 when products are included (as compared to a short process-only regime). Interestingly, the $R \& D$ share and its interaction are not significant in the earlier time period. The fact that we observe less benefit from product patents in the full period data and a more negative effect associated with local R\&D activity (compare Tables 6, 7 and 8) may be due to innovator firms feeling increasingly less able to make use of patent rights in developing countries to protect against local competition.

Policy choices have remarkably different effects on whether drugs are "ever" launched. Contrary to the finding for rapid launch, there is only weak evidence that moving from a short to a long process patent regime increases the likelihood of a drug being marketed ever. Instead, there is a significant benefit in the longer term associated with giving short-term protection to innovative products, increasing the estimated probability that a drug is ever launched in a lowerincome country by 7.5 percentage points or $25 \%$.

Most interestingly, there is a significant, sizable, and now positive benefit associated with having local technical capacity. Moving from no local research activity to the mean R\&D share in this sample of 0.38 increases the probability that a new NCE is ever launched in a country by an estimated 9.7 percentage points or $32 \%$. Further, in contrast to our finding for rapid launch that strong patent protection partially and positively offsets the harmful effect of local capacity, 
when it comes to the question of whether new drugs are ever marketed, we find that strong patent protection negatively offsets the otherwise beneficial effect of having local capacity. Further, the offset is no longer partial. The joint marginal effect of $R \& D$ capacity when combined with extensive IP protection is a statistically insignificant 0.07 (p-value 0.256). Consistent with this contrast in the direction of effects across time lags, we also find here that offering a patent term extension has a weakly significant negative effect on whether new drugs are ever launched, whereas for rapid launch this policy was found to be either insignificant or positive.

One surprise in Table 8 is that price regulation, which has a large and consistently negative effect on the likelihood that a drug is launched quickly, is estimated to have a weakly positive effect on whether drugs are ever launched. This is difficult to explain either as a direct effect, or as the result of policy endogeneity, both of which would give a negative effect. Nor is it consistent with the idea that regulators lower price demands if firms hold out long enough to entice them into the market, since such behavior would, at best, make regulation neutral. At the very least, it does not appear that price regulation is severely limiting the ultimate entry of new products.

Taken together, the findings in column two of Table 8 suggest that innovator firms are an important source of drug entry (hence product patents matter for eventual launch) and that these firms are willing to enter poorer markets at low prices with only a few years of effective patent protection - after some delay. They also suggest that local firms can be a significant source of market entry, and that their ability to actively enter could be slowed by stronger patent rights. Given this, unless speed of access is paramount, a lower-income country would not seem to benefit in terms of greater product availability from offering a long term of product patent protection or from limiting its price control regulation. 
Finally, Table 9 presents hazard model estimates. There are in an accelerated failure time form which means that a negative coefficient is associated with shorter launch lags and thus corresponds to a positive coefficient in the probit estimations. The hazard model summarizes the effect of policy on launch behavior at all monthly lags after global launch and thus incorporates within a specific structure - both the "within two year" and "within ten year" launch probabilities. Thus it is not surprising to see in the first column of Table 9 that both increasing the term on process patents and making short protection available on new products speed drug launch. ${ }^{35}$ We find that while extensive price regulation slows launch, moderate price regulation, on average, has no effect in this group of low- and middle-income countries.

\section{High-income Countries}

There is less variation in the patent regimes observed in the high-income countries. For example, all of the countries in this group offered at least protection on pharmaceutical processes over most of the period. Thus, for this group of countries the set of indicator variables is limited to three: a dummy for whether a country protects pharmaceutical products, another for the incremental effect of having a long statutory term on either form of protection, and finally a dummy variable indicating whether a patent term extension is available. For this group of countries, "Short" refers to a statutory term of less than 20 years, the distinction preferred by the data.

The estimations in Table 10 for the high-income countries and the full set of NCE follow the same format as Table 6. For this set of countries the estimates on the policy variables are less

${ }^{35}$ From Table 8 it is clear that a model allowing for changes in the relative effect of policy variables at different lags would be desirable. A Cox proportionate hazard specification accommodates this easily but the underlying proportionality assumption is resoundingly rejected by the data. 
robust to the choice of fixed or random country effects (compare models one and two). ${ }^{36}$ It may be that the policy variables are picking up some the effect of other country level characteristics in the random effects specification. However, it is also the case that among the high-income countries there is more limited within-country variation in the policy variables (see Table A4). As a result the countries contributing to the estimation of policy effects across the two specifications are quite different and this makes some divergence in the point estimates less surprising. We also test formally, as above, the hypothesis that the extensive price control variable is exogeneous and again cannot reject the null $\left(\chi^{2}(1)=0.84\right.$, p-value $\left.=0.36\right)$. First-stage estimates are in Appendix Table A5.

The results in Table 10 consistently indicate that adding the protection of new products to an otherwise "Short" patent regime gives the greatest incremental boost to rapid market entry. For the specification with country fixed effects, shown in column one, we also find a significant additional benefit from moving to a longer patent term. However, in no specification is there any evidence that having a drug patent extension affects the market entry of new pharmaceuticals within high-income countries.

All price regulation - whether moderate or extensive - tends to reduce the probability that a drug is launched in a high-income country within two years. However, as for the poorer countries, the effect of moderate price regulation depends on the income level of a country. The estimates here indicate that moderate price control no longer lowers the probability of rapid entry once a country reaches a GDP per capita of about $\$ 12,088$, slightly below the median level for the group.

\footnotetext{
${ }^{36}$ However, the standard errors are sizable so the estimates are statistically indistinguishable at conventional levels.
} 
The first column of Table 11 contains estimation results for the "high quality" subset of NCE using the country fixed-effects specification. The overall probability of a high quality drug being launched within 2 years is over fifty percent higher than for an average NCE (33\% vs. 20\%). As for all drugs, short-term product patent protection encourages the launch of blockbusters. In contrast to all drugs, however, there is no incremental benefit from having the longest term of protection. Having any price control lowers the likelihood of entry and extensive price control is particularly problematic. The latter lowers the probability of rapid launch by 10.7 percentage points, or $33 \%$.

The last results in Table 11 are within 2 and within 10 year estimates for the early (198292) period NCE. Because of the limited within-country variation in the policy variables during this shorter period, we use the random effects specification corresponding to column three in Table 10.

A high-income country increases the probability that new drugs are available to its consumers quickly by offering at least short-term protection to pharmaceutical products, as before, but for this early period there is an even larger incremental effect from moving to a longer term of protection (column 2). Moderate price control is weakly significant and extensive price control significantly diminishes the likelihood of rapid entry.

When considering whether drugs are "ever" launched in the high-income countries both patents and price regulation continue to have a role. In this longer time span, however, it is only long-term patent protection that is found to make a positive contribution. Recall from Figure 1 that later market entry implies a shorter effective patent life. Thus, the statutory term may need to be long if it is to create a period of exclusivity sufficient to allow a firm to cover the higher costs of entry into high-income countries. It is somewhat surprising, then, to continue to find 
that offering a patent term extension has no discernible effect on eventual market entry nor on its timing. Finally, and again as we found for the poorer countries, extensive price control is far less damaging to the likelihood that a drug is ever launched than it is to the likelihood that it is launched quickly.

Maintaining an essential drugs list was found to have a significant dampening effect on market entry in the poorer countries in most specifications. We see the same negative effect within the high-income countries when considering all drugs, and of a similar relative magnitude. Having a national formulary is also associated with less rapid entry. Finally there is some evidence that the establishment of the European Medicines Evaluation Agency in 1995 as a centralized mechanism for obtaining marketing approvals within Europe has succeeded in speeding access to new drugs for consumers there. In specifications where the estimated effect of the EMEA is significant it is also large - increasing the probability of launch within 2 years by $25-30 \%$.

\section{Income Distribution and Demographic Characteristics}

As one would expect, having a larger population and higher level of GDP per capita increases the likelihood that a country will have more drugs on the market and that they will become available quickly. In the estimations that include the Gini coefficient as a measure of income inequality, we find that the distribution of income is always also a significant determinant of market entry. The Gini coefficient, and its interaction with the log of GDP per capita, are statistically significant and show a pronounced pattern across the two income groups. As noted in the introduction, when an innovator firm considers launching products in one of the poorer countries, it may follow a strategy of setting low prices with small profit margins in an attempt to achieve extensive market penetration. Alternatively it may opt for higher prices with 
the expectation of reaching just the top of the market. We find that a lower-income country is more likely to get new drugs if it is unequal - ensuring that it has a wealthy "elite". On the other hand, a high-income country is better off with a more equal distribution as this generates the largest "middle class". Equality becomes less important as average income increases. These findings are consistent with the idea that there is a threshold level of income that makes an individual a potential consumer of new drugs. For countries with an average income below that threshold, inequality increases market size. For those above, inequality decreases market size unless average income is so high that even when it is unequally distributed most consumers are above the threshold.

The age composition of a country's population also appears as a very significant determinant of the speed and extent of drug launch. In the low- and middle-income countries, drugs are more likely to reach the market in countries with many children and those with a high proportion of elderly. In the high- income countries, having a larger proportion of children seems to be most important.

\section{Policy Simulations}

This section gives a sense of the empirical implications of the econometric results discussed above. Table 12 gives the predicted probability that a drug arrives in a given country market within two years of its global launch. The predictions are for 1995 and the anti-infectives therapy class. They are based on the estimation of country fixed-effects models, using the high quality NCE for the high-income countries (Table 10, column 1) and the blockbuster sample for the low- and middle-income countries (unreported). The columns on the left hand side indicate a range of different policy choices, while those on the right show how the predicted probabilities 
vary with these choices. The last row gives selected estimated standard errors - to give a sense of the precision of the predictions. Because the predictions are highly correlated across rows within a given column, and across columns within income groups, these should not be used to formally assess the statistical significance of differences. Bold typeface indicates changes that are significant.

The first three rows change the patent regime, while the last three rows change price regulation. It is apparent from this table that a country's choices regarding intellectual property and price regulation can have a substantial impact on the likelihood that new pharmaceuticals are available to consumers quickly. In both lower- and high-income countries there appears to be scope to alter the probabilities by some $20-30 \%$ or more by virtue of these policy decisions.

Figure 5 presents this finding in another form using the hazard model estimates in Table 9. It gives predicted cumulative hazard rates for India. Each line represents the time path of market launches assuming different combinations of intellectual property and price control (PC) policies. As in Table 12, the predictions are for 1995 and the anti-infectives therapy class. The pair of policies indicated in the top row change the patent term, while the pair in the second row change the degree of price regulation. These two changes generate similar-sized shifts in the cumulative hazard curves.

The vertical axis indicates the predicted share of drugs launched in the given market by the lag indicated on the horizontal axis. Considering the upper dashed and dotted lines that overlay each other, for example, we see that if India were to have some price control and also offer long ( $\geq 15$ years) patent protection, a predicted $20 \%$ of all NCE would be marketed there within about five years of their global launch dates. Suppose that India then kept the longer term of patent protection but moved to more extensive price regulation (the lower solid line). 
One can ask the question: how many fewer drugs would arrive within five years with the new policy? Looking vertically at five years, the answer is that just $15 \%$ of all drugs - rather than the previous $20 \%$ - would be launched within this period as a result of the change in policy. One can also ask the question: with the new policy, how much longer would it take for $20 \%$ of all drugs to be launched? Looking horizontally, the answer is that it would take some six and a half years - rather than five - as a result of the change in policy. Irrespective of policy regime, ten years after global launch no more than $40 \%$ of all drugs are predicted to be on the Indian market.

\section{Concluding Comments}

Much attention has been paid to how price controls and the patent system determine pharmaceutical prices. We find that countries' choices about how to regulate pharmaceutical prices and protect innovation also have a significant influence on whether drugs become available to their consumers and how quickly. Short-term patent protection that includes products, or long protection only of manufacturing processes, are both patent regimes that tend to encourage more or faster launches in the developing world. Increasing the strength of a patent system to include long-term protection on pharmaceutical products appears to spur market entry - among the high-income countries. For the low- and middle-income countries that are currently being encouraged to move to stronger protection through trade policy, the evidence that extending protection enhances access to new pharmaceuticals is mixed. There is some evidence that high levels of protection might encourage more frequent entry of innovative products in the short term, particularly in countries where multinationals might otherwise hesitate because local technical capacity might create competitive pressures. On the other hand, in the longer term that same domestic capacity could be an alternative source of entry, and we find that a country 
offering extensive patent protection may lose the benefits of that activity and have fewer new products in the market overall as a result.

The fact that patent laws in the low- and middle-income countries are shown to matter at all is also of significance. Intellectual property holders frequently assert that the poor quality of enforcement in developing countries undermines the value of their patent rights. With the patent variables significant in various estimations, and entering with different and plausible patterns across subsets of the NCE, it is evident that patent laws in these countries are at least broadly meaningful.

Like intellectual property, the standard argument regarding price regulation - that it will dissuade market entry - appears to have more relevance among the high-income countries. For these countries, extensive price control is always found to lower the probability of market entry, and moderate regulation appears to do likewise, even in the long run. Not so for the poorer countries. There we find that while price regulation makes it less likely that new drugs will be available quickly, it does not appear to prevent new products from being launched eventually.

As they stand these results might temper some of the arguments made in the course of future international negotiations. Interpreting what they imply for public health and social welfare will require further analysis. If, for example, ten percent of new drugs are no longer marketed in a country due to a policy change, this may be damaging or not depending on what was in that ten percent. Pharmaceuticals often have acceptable substitutes, and some "lifestyle" drugs may not be of great medicinal importance. Future research will explore the therapeutic significance of the pharmaceuticals that are launched slowly, or not at all, and the extent to which this failure is associated with there being substitutes available in the market. 
A very poor country may also be quite willing to accept some delay in the arrival of innovative new pharmaceuticals as a result of regulation if it means that the drugs are priced within reach of more of the population when they finally reach the market. With cross-country data on product prices, this tradeoff could be assessed. Finally, giving innovators the strongest patent protection might be viewed as worthwhile irrespective of its effect on entry, on the grounds that it might boost R\&D and the discovery of new NCE. 


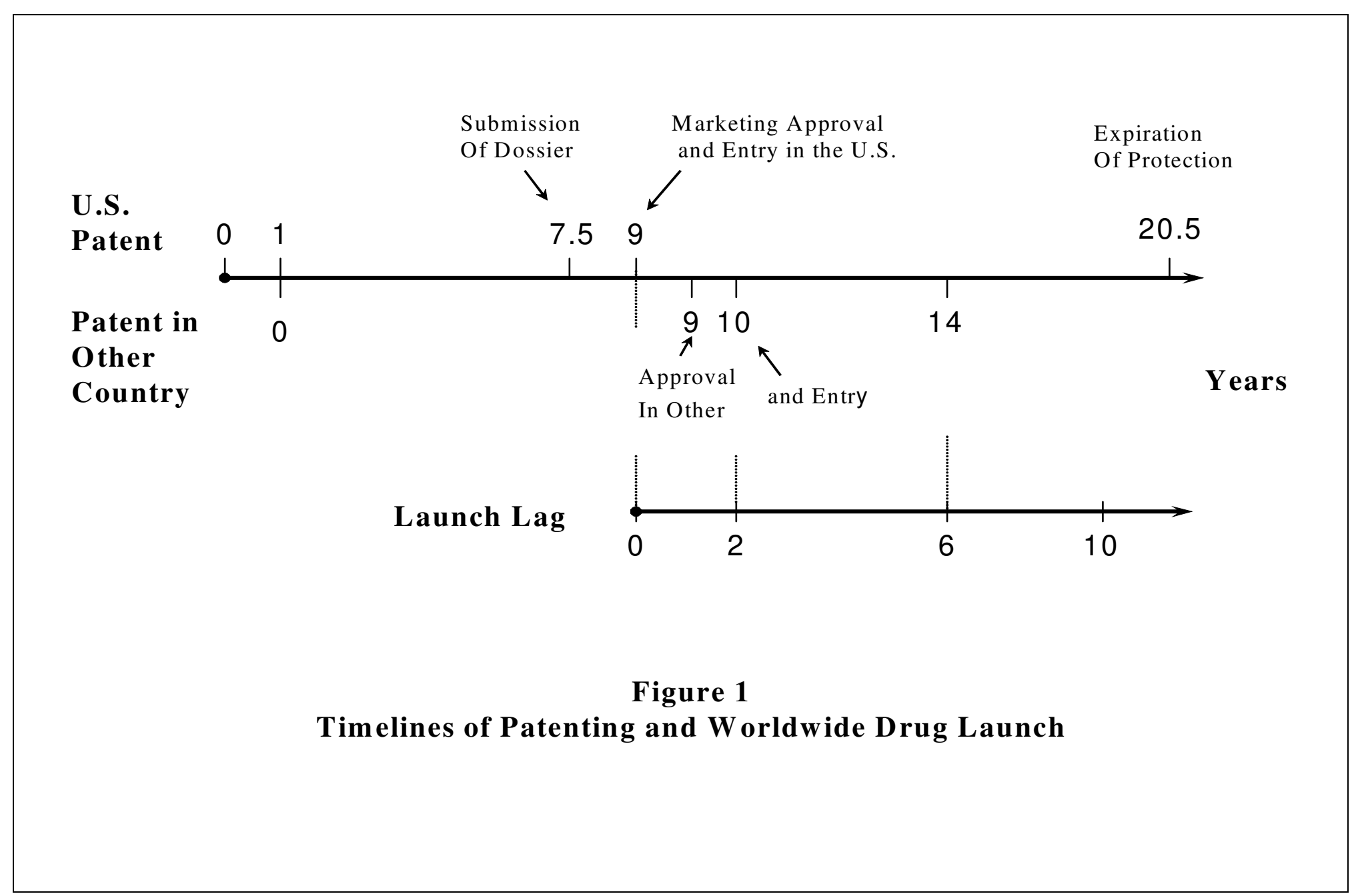




\begin{tabular}{|c|c|c|}
\hline \multicolumn{3}{|c|}{$\begin{array}{c}\text { Table } 1 \\
\text { NCE Global Launches per Year }\end{array}$} \\
\hline Year & $\begin{array}{c}\text { Annual } \\
\text { Blockbusters }\end{array}$ & $\begin{array}{c}\text { Total } \\
\text { New Drugs }\end{array}$ \\
\hline 1982 & 4 & 36 \\
\hline 1983 & 4 & 29 \\
\hline 1984 & 2 & 34 \\
\hline 1985 & 8 & 58 \\
\hline 1986 & 10 & 45 \\
\hline 1987 & 9 & 55 \\
\hline 1988 & 7 & 43 \\
\hline 1989 & 6 & 38 \\
\hline 1990 & 12 & 42 \\
\hline 1991 & 5 & 39 \\
\hline 1992 & 4 & 43 \\
\hline 1993 & 6 & 37 \\
\hline 1994 & 9 & 41 \\
\hline 1995 & 13 & 39 \\
\hline 1996 & 13 & 42 \\
\hline 1997 & 13 & 43 \\
\hline 1998 & 13 & 39 \\
\hline 1999 & 6 & 44 \\
\hline 2000 & 5 & 35 \\
\hline $\begin{array}{l}\text { Note: Blc } \\
\text { the top } 21 \\
\text { in } 1998 \text { o } \\
\text { U.S. reve }\end{array}$ & $\begin{array}{l}\text { buster drugs are } \\
\text { drugs in terms o } \\
003 \text { or among th } \\
\text { e in } 1993 \text { or } 199\end{array}$ & $\begin{array}{l}\text { JCE among } \\
\text { world revenue } \\
\text { top } 100 \text { in }\end{array}$ \\
\hline
\end{tabular}




\begin{tabular}{|c|c|c|c|}
\hline \multicolumn{4}{|c|}{$\begin{array}{r}\text { Table } 2 \\
\text { Location of First Launch: Distrib }\end{array}$} \\
\hline Country & $\begin{array}{l}\text { No. First } \\
\text { Launches }\end{array}$ & $\begin{array}{c}\text { Years } \\
\text { of Data }\end{array}$ & $\begin{array}{c}\text { Pct. Of First } \\
\text { Launches } \\
\text { (Adjusted Share) }\end{array}$ \\
\hline High Income Countries & & & \\
\hline AUSTRALIA & 3 & 21 & 0.28 \\
\hline AUSTRIA & 12 & 21 & 1.28 \\
\hline BELGIUM & 6 & 21 & 0.54 \\
\hline CANADA & 10 & 21 & 1.02 \\
\hline DENMARK & 18 & 21 & 1.82 \\
\hline FINLAND & 12 & 21 & 1.19 \\
\hline FRANCE & 44 & 21 & 4.38 \\
\hline GERMANY & 74 & 21 & 7.36 \\
\hline GREECE & 1 & 21 & 0.10 \\
\hline HONG KONG & 1 & 21 & 0.09 \\
\hline IRELAND & 15 & 21 & 1.53 \\
\hline ISRAEL & 1 & 21 & 0.10 \\
\hline ITALY & 61 & 21 & 6.08 \\
\hline JAPAN & 231 & 21 & 23.99 \\
\hline NETHERLANDS & 26 & 21 & 2.89 \\
\hline NEW ZEALAND & 7 & 19 & 0.80 \\
\hline NORWAY & 6 & 10 & 1.33 \\
\hline PORTUGAL & 3 & 21 & 0.30 \\
\hline PUERTO RICO & 16 & 9 & 3.68 \\
\hline SINGAPORE & 6 & 19 & 0.70 \\
\hline SPAIN & 23 & 21 & 2.38 \\
\hline SWEDEN & 26 & 21 & 2.66 \\
\hline SWITZERLAND & 36 & 21 & 3.67 \\
\hline UK & 72 & 21 & 7.30 \\
\hline USA & 163 & 21 & 16.95 \\
\hline Upper Income Countries & & & \\
\hline ARGENTINA & 7 & 21 & 0.72 \\
\hline BOLIVIA & 1 & 11 & 0.24 \\
\hline BRAZIL & 3 & 21 & 0.26 \\
\hline CHILE & 1 & 21 & 0.10 \\
\hline CZECH REPUBLIC & 1 & 10 & 0.20 \\
\hline MALAYSIA & 5 & 21 & 0.53 \\
\hline MEXICO & 16 & 21 & 1.66 \\
\hline POLAND & 1 & 11 & 0.20 \\
\hline SOUTH AFRICA & 6 & 21 & 0.65 \\
\hline SOUTH KOREA & 1 & 15 & 0.11 \\
\hline TURKEY & 1 & 21 & 0.09 \\
\hline VENEZUELA & 6 & 21 & 0.58 \\
\hline Lower Income Countries & & & \\
\hline COLOMBIA & 1 & 21 & 0.07 \\
\hline DOMINICAN REPUBLIC & 1 & 17 & 0.10 \\
\hline PERU & 1 & 21 & 0.12 \\
\hline PHILIPPINES & 4 & 21 & 0.45 \\
\hline RUSSIA & 2 & 8 & 0.56 \\
\hline THAILAND & 2 & 21 & 0.19 \\
\hline Low Income Countries & & & \\
\hline BANGLADESH & 1 & 10 & 0.19 \\
\hline FRENCH WEST AFRICA & 2 & 11 & 0.40 \\
\hline PAKISTAN & 1 & 21 & 0.08 \\
\hline
\end{tabular}




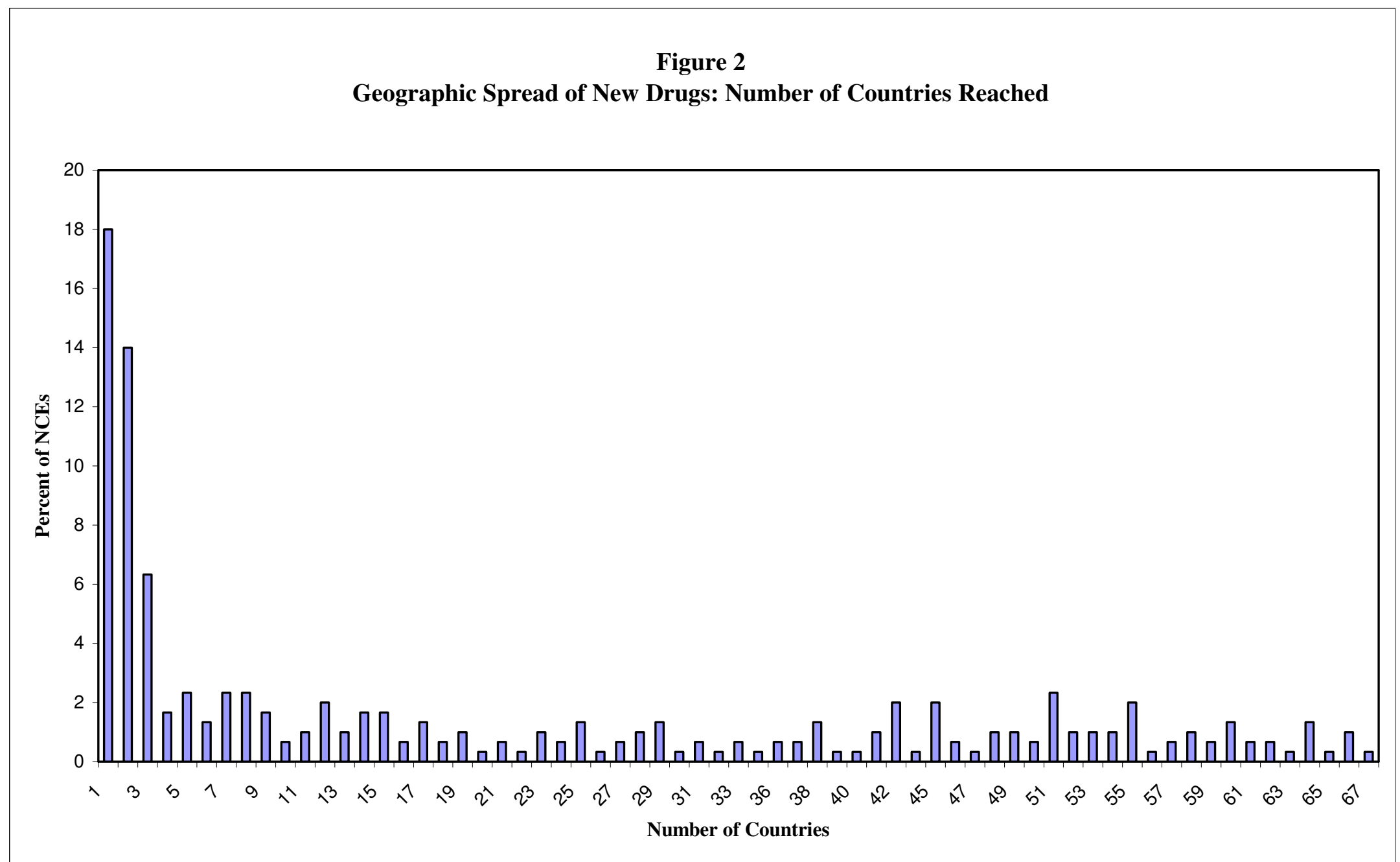

Note: This figure includes the 300 drugs first launched 1/82 through 12/88. 


\begin{tabular}{|c|c|c|c|c|c|c|c|c|c|}
\hline \multicolumn{10}{|c|}{$\begin{array}{l}\text { Table } 3 \\
\text { Launch Lags for NCEs that were First Marketed 1986-1992 } \\
\text { (Months) }\end{array}$} \\
\hline \multirow[b]{2}{*}{ Country } & \multirow[b]{2}{*}{ \# Drugs } & \multicolumn{2}{|c|}{ Percentiles } & \multirow[b]{2}{*}{$90^{\text {th }}$} & \multirow[b]{2}{*}{ Country } & \multicolumn{4}{|c|}{ Percentiles } \\
\hline & & $10^{\text {th }}$ & Median & & & \# Drugs & $10^{\text {th }}$ & Median & $90^{\text {th }}$ \\
\hline High Income & & & & & Upper Income & & & & \\
\hline AUSTRALIA & 28 & 15 & 46.5 & 111 & ARGENTINA & 49 & 8 & 36 & 110 \\
\hline AUSTRIA & 46 & 12 & 28.5 & 73 & BRAZIL & 43 & 22 & 52 & 131 \\
\hline BELGIUM & 40 & 6.5 & 23 & 90.5 & CHILE & 39 & 13 & 41 & 104 \\
\hline CANADA & 34 & 4 & 32.5 & 69 & LEBANON & 26 & 46 & 106 & 157 \\
\hline DENMARK & 40 & 0.5 & 18 & 68 & MALAYSIA & 26 & 26 & 50.5 & 138 \\
\hline FINLAND & 38 & 11 & 27.5 & 85 & MEXICO & 44 & 8 & 29 & 102 \\
\hline FRANCE & 41 & 0 & 19 & 62 & POLAND & 6 & 34 & 43.5 & 98 \\
\hline GERMANY & 54 & 0 & 18.5 & 45 & SAUDI ARABIA & 29 & 32 & 51 & 107 \\
\hline GREECE & 44 & 13 & 37 & 120 & SOUTH AFRICA & 37 & 10 & 30 & 100 \\
\hline HONG KONG & 37 & 13 & 27 & 88 & SOUTH KOREA & 53 & 24 & 49 & 110 \\
\hline IRELAND & 38 & 0 & 22.5 & 88 & TAIWAN & 5 & 55 & 83 & 116 \\
\hline ISRAEL & 29 & 28 & 52 & 102 & TURKEY & 40 & 23 & 55.5 & 95 \\
\hline ITALY & 57 & 0 & 24 & 74 & VENEZUELA & 38 & 17 & 35.5 & 115 \\
\hline JAPAN & 77 & 0 & 0 & 85 & Lower Income & & & & \\
\hline NETHERLANDS & 47 & 4 & 22 & 49 & CENTRAL AMERICA & 43 & 18 & 46 & 136 \\
\hline NEW ZEALAND & 36 & 5 & 26.5 & 79 & $\begin{array}{l}\text { COLOMBIA } \\
\text { DOMINICAN }\end{array}$ & 42 & 17 & 44.5 & 104 \\
\hline PORTUGAL & 33 & 20 & 49 & 88 & REPUBLIC & 35 & 25 & 49 & 111 \\
\hline SINGAPORE & 33 & 18 & 45 & 109 & ECUADOR & 37 & 20 & 55 & 118 \\
\hline SPAIN & 37 & 18 & 30 & 111 & EGYPT & 30 & 37 & 73.5 & 133 \\
\hline SWEDEN & 46 & 0 & 17 & 86 & LATVIA & 20 & 63 & 99.5 & 142 \\
\hline SWITZERLAND & 46 & 2 & 14 & 66 & MOROCCO & 29 & 14 & 45 & 140 \\
\hline UK & 50 & 0 & 16 & 51 & PERU & 36 & 24 & 57.5 & 159 \\
\hline \multirow[t]{2}{*}{ USA } & 46 & 0 & 20 & 69 & PHILIPPINES & 49 & 6 & 35 & 98 \\
\hline & & & & & THAILAND & 48 & 16 & 41.5 & 99 \\
\hline
\end{tabular}




\begin{tabular}{|c|c|c|c|c|}
\hline \multirow[b]{2}{*}{ Country } & & Perce & tiles & \\
\hline & \# Drugs & $10^{\text {th }}$ & Median & $90^{\text {th }}$ \\
\hline \multicolumn{5}{|l|}{ Low Income } \\
\hline FRENCH WEST AFRICA & 10 & 19 & 47 & 131 \\
\hline INDIA & 14 & 46 & 58 & 84 \\
\hline INDONESIA & 42 & 22 & 43 & 97 \\
\hline PAKISTAN & 38 & 23 & 57 & 118 \\
\hline \multicolumn{5}{|l|}{ (Unweighted) Means } \\
\hline High Income & 42.5 & 7.4 & 26.8 & 81.2 \\
\hline Upper Middle Income & 33.5 & 24.5 & 50.9 & 114.1 \\
\hline Lower Middle Income & 36.9 & 24.0 & 54.7 & 123.9 \\
\hline Low Income & 26.0 & 27.5 & 51.3 & 107.5 \\
\hline \multicolumn{5}{|c|}{$\begin{array}{l}\text { Notes: The sample includes the } 122 \mathrm{NCE} \text { from the therapy classes A2B, } \\
\mathrm{C}, \mathrm{J} \text { for which Indian data are available and, for a given country, only those } \\
\text { NCE first marketed after the country entered the database. }\end{array}$} \\
\hline
\end{tabular}


Table 4: The Arrival of New Drugs

Percent Released:

\begin{tabular}{|c|c|c|}
\hline All & $\begin{array}{l}\text { Upper } \\
\text { Bound }\end{array}$ & $\begin{array}{l}\text { Block- } \\
\text { Buster }\end{array}$ \\
\hline $25 \%$ & $28 \%$ & $67 \%$ \\
\hline 38 & 43 & 81 \\
\hline 31 & 36 & 67 \\
\hline 30 & 35 & 81 \\
\hline 36 & 39 & 81 \\
\hline 33 & 37 & 78 \\
\hline 37 & 43 & 71 \\
\hline 44 & 57 & 86 \\
\hline 34 & 36 & 84 \\
\hline 29 & 33 & 73 \\
\hline 32 & 36 & 75 \\
\hline 26 & 30 & 75 \\
\hline 49 & 54 & 82 \\
\hline 53 & 59 & 68 \\
\hline 37 & 42 & 79 \\
\hline 28 & 30 & \\
\hline 29 & 34 & 69 \\
\hline 26 & 26 & 56 \\
\hline 36 & 40 & 80 \\
\hline 34 & 37 & 78 \\
\hline 36 & 48 & 80 \\
\hline 40 & 45 & 84 \\
\hline 38 & 46 & 90 \\
\hline 42 & 47 & 84 \\
\hline 32 & 36 & 76 \\
\hline 30 & 35 & 77 \\
\hline 22 & 24 & 55 \\
\hline 35 & 38 & 79 \\
\hline 23 & 26 & 70 \\
\hline 29 & 31 & 74 \\
\hline 31 & 34 & 81 \\
\hline 26 & 28 & 77 \\
\hline 31 & 35 & 82 \\
\hline 31 & 35 & 82 \\
\hline 27 & 30 & 74 \\
\hline 19 & 21 & 62 \\
\hline 25 & 28 & 67 \\
\hline 36 & 44 & 81 \\
\hline 34 & 35 & 80 \\
\hline 26 & 28 & 75 \\
\hline 26 & 28 & 66 \\
\hline
\end{tabular}

Percentage Marketed - Years After Global Launch:

\begin{tabular}{|c|c|c|c|c|c|c|c|c|c|}
\hline & 1 & 2 & 3 & 4 & 5 & 6 & 7 & 8 & 9 \\
\hline AUSTRALIA & $5 \%$ & $18 \%$ & $39 \%$ & $57 \%$ & $68 \%$ & $74 \%$ & $83 \%$ & $88 \%$ & $98 \%$ \\
\hline AUSTRIA & 13 & 30 & 51 & 66 & 74 & 83 & 87 & 94 & 98 \\
\hline BELGIUM & 19 & 40 & 61 & 72 & 79 & 85 & 91 & 94 & 97 \\
\hline CANADA & 19 & 34 & 56 & 65 & 78 & 89 & 91 & 96 & 97 \\
\hline DENMARK & 26 & 48 & 65 & 75 & 84 & 89 & 93 & 95 & 97 \\
\hline FINLAND & 11 & 33 & 54 & 67 & 74 & 80 & 87 & 93 & 96 \\
\hline FRANCE & 35 & 49 & 62 & 70 & 79 & 85 & 91 & 94 & 100 \\
\hline GERMANY & 32 & 60 & 75 & 83 & 87 & 91 & 94 & 98 & 94 \\
\hline GREECE & 6 & 23 & 41 & 56 & 69 & 78 & 85 & 91 & 97 \\
\hline HONG KONG & 13 & 37 & 62 & 70 & 76 & 79 & 86 & 93 & 97 \\
\hline IRELAND & 28 & 50 & 60 & 69 & 77 & 83 & 88 & 94 & 98 \\
\hline ISRAEL & 3 & 17 & 27 & 52 & 69 & 74 & 83 & 93 & 98 \\
\hline ITALY & 33 & 46 & 60 & 71 & 78 & 86 & 92 & 95 & 97 \\
\hline JAPAN & 64 & 68 & 73 & 78 & 83 & 88 & 91 & 93 & 98 \\
\hline NETHERLANDS & 31 & 53 & 68 & 79 & 84 & 90 & 92 & 94 & 94 \\
\hline NEW ZEALAND & 20 & 41 & 53 & 65 & 72 & 81 & 86 & 91 & 97 \\
\hline PORTUGAL & 11 & 23 & 40 & 47 & 65 & 76 & 84 & 91 & 98 \\
\hline SINGAPORE & 14 & 35 & 53 & 66 & 76 & 82 & 89 & 95 & 96 \\
\hline SPAIN & 12 & 28 & 48 & 61 & 70 & 78 & 85 & 92 & 98 \\
\hline SWEDEN & 30 & 48 & 57 & 70 & 76 & 83 & 88 & 94 & 96 \\
\hline SWITZERLAND & 35 & 56 & 70 & 79 & 83 & 87 & 90 & 92 & 98 \\
\hline UK & 44 & 60 & 72 & 79 & 86 & 91 & 95 & 97 & 98 \\
\hline USA & 34 & 48 & 62 & 71 & 78 & 89 & 93 & 94 & 93 \\
\hline ARGENTINA & 13 & 27 & 44 & 60 & 70 & 76 & 80 & 84 & 92 \\
\hline BRAZIL & 7 & 20 & 34 & 50 & 62 & 70 & 76 & 85 & 95 \\
\hline CHILE & 7 & 25 & 43 & 53 & 65 & 74 & 83 & 91 & 99 \\
\hline MALAYSIA & 13 & 33 & 56 & 76 & 83 & 88 & 91 & 94 & 98 \\
\hline MEXICO & 14 & 33 & 47 & 60 & 73 & 81 & 87 & 93 & 95 \\
\hline SAUDI ARABIA & 1 & 5 & 16 & 33 & 50 & 65 & 75 & 89 & 98 \\
\hline SOUTH AFRICA & 15 & 35 & 53 & 63 & 69 & 77 & 84 & 91 & 96 \\
\hline TURKEY & 1 & 10 & 24 & 35 & 52 & 64 & 76 & 88 & 94 \\
\hline VENEZUELA & 4 & 21 & 38 & 50 & 64 & 75 & 84 & 90 & 95 \\
\hline CENTRAL & & & & & & & & & \\
\hline AMERICA & 3 & 19 & 35 & 46 & 63 & 72 & 81 & 88 & 97 \\
\hline COLOMBIA & 6 & 15 & 30 & 47 & 59 & 67 & 79 & 85 & 91 \\
\hline ECUADOR & 3 & 10 & 25 & 35 & 53 & 67 & 78 & 82 & 90 \\
\hline EGYPT & 0 & 2 & 7 & 19 & 29 & 48 & 63 & 74 & 94 \\
\hline PERU & 3 & 11 & 26 & 37 & 51 & 62 & 73 & 80 & 93 \\
\hline PHILIPPINES & 8 & 25 & 44 & 58 & 67 & 74 & 83 & 86 & 93 \\
\hline THAILAND & 5 & 23 & 41 & 55 & 63 & 71 & 80 & 88 & 96 \\
\hline INDONESIA & 0 & 9 & 30 & 45 & 57 & 68 & 80 & 88 & 92 \\
\hline PAKISTAN & 2 & 10 & 18 & 34 & 49 & 61 & 69 & 78 & $95 \%$ \\
\hline
\end{tabular}

Notes: "Percent Released" is the share of global NCE launched in the row country within 10 years. "Upper Bound" assumes all observations with missing ingredient information are NCEs and grosses up the total launches accordingly. 


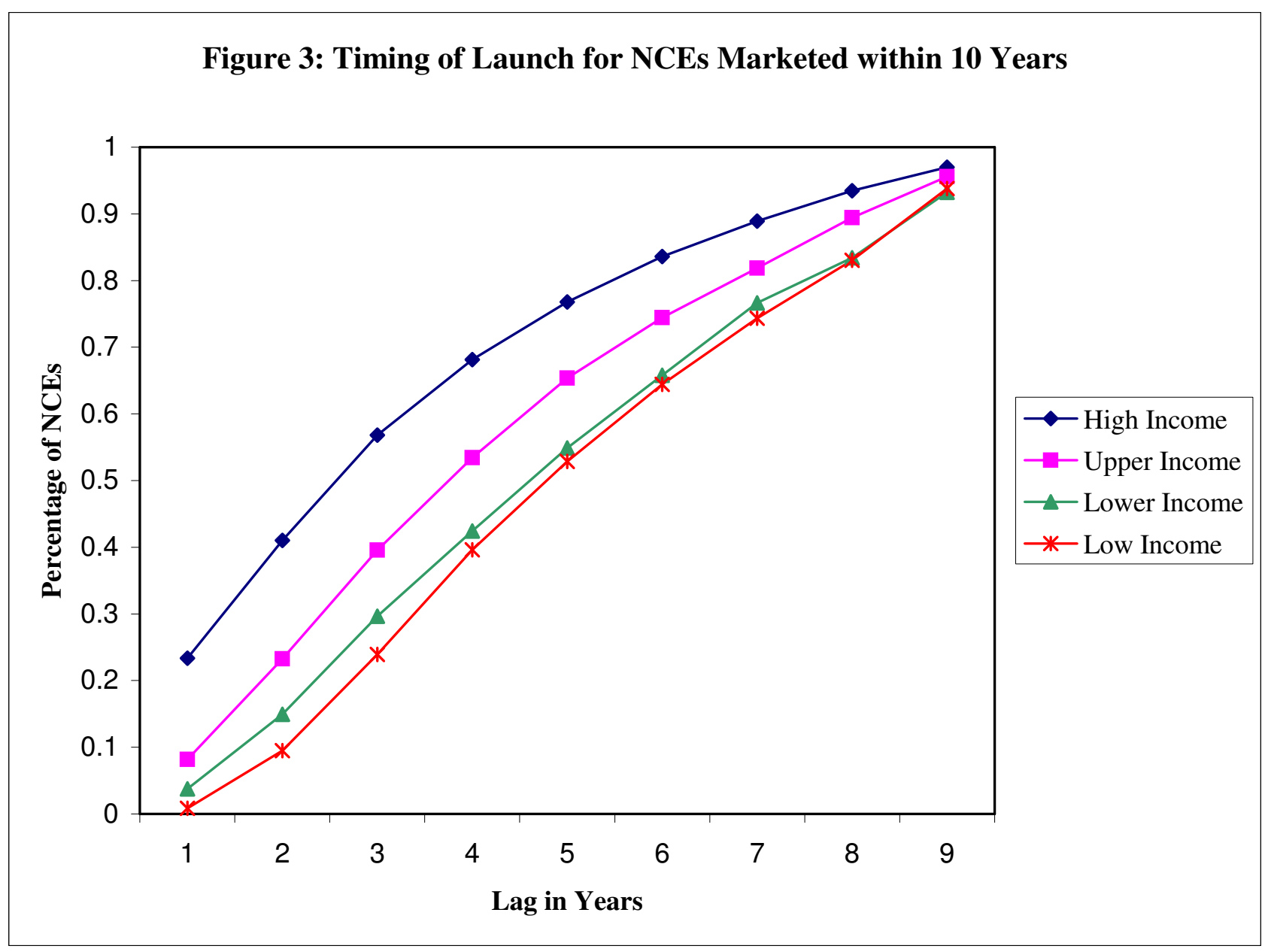


Table 5

Percent of NCE Launches 1982-92 done by "First" Firm

By Type of Patent Regime

\begin{tabular}{llllll}
$\begin{array}{l}\text { Group } \\
\text { No. launches) }\end{array}$ & $\begin{array}{l}\text { Short Process } \\
\text { or None }\end{array}$ & $\begin{array}{l}\text { Short Product } \\
\text { and Process }\end{array}$ & $\begin{array}{l}\text { Long Process } \\
\text { Only }\end{array}$ & $\begin{array}{l}\text { Long Product } \\
\text { and Process }\end{array}$ & $\begin{array}{l}\text { All } \\
\text { Countries }\end{array}$ \\
All Drugs & $54.8 \%$ & $67.5 \%$ & $68.0 \%$ & $71.7 \%$ & $61.6 \%$ \\
& $(5,430)$ & $(332)$ & $(842)$ & $(2,963)$ & $(9,567)$ \\
Blockbusters & 65.6 & 75.1 & 72.2 & 76.9 & 72.3 \\
& $(1,154)$ & $(189)$ & $(461)$ & $(1,577)$ & $(3,381)$ \\
\hline
\end{tabular}

Notes: The "first" firm is defined as the one making the first launch in a high-income country. The number of observations in each cell is in parentheses. A "short" patent regime is one with a statutory term of less than 15 years. 


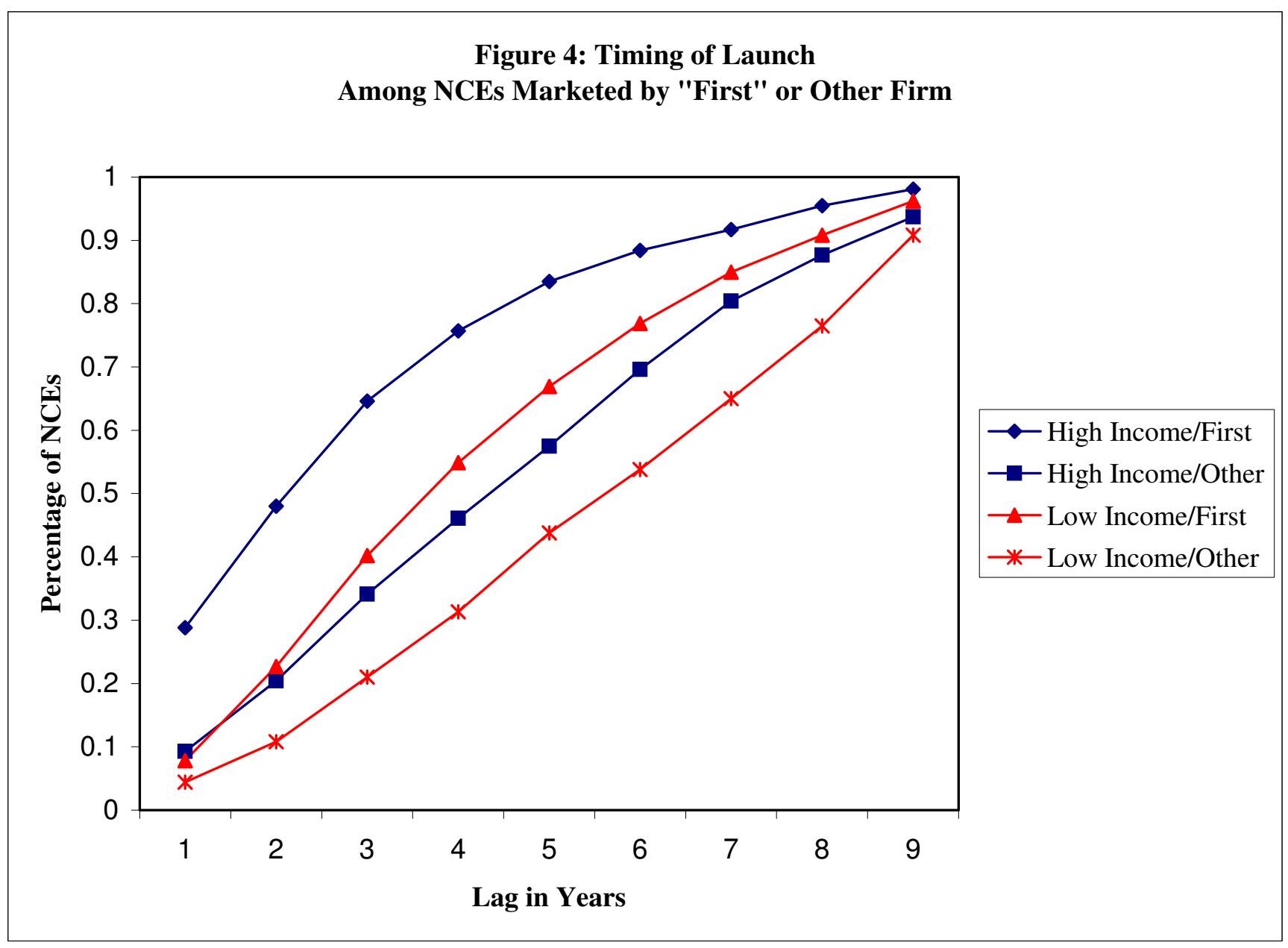




\begin{tabular}{|c|c|c|c|c|}
\hline \multicolumn{5}{|c|}{$\begin{array}{l}\text { Table 6: Low- and Middle-Income Countries } \\
\text { Probability of Launch within Two Years }\end{array}$} \\
\hline & \multicolumn{2}{|c|}{ With Country Fixed Effects } & \multicolumn{2}{|c|}{ Without Country FE } \\
\hline Policy Variables & $\begin{array}{c}\text { Marginal } \\
\text { Effect }\end{array}$ & Estimated S.E. & $\begin{array}{l}\text { Marginal } \\
\text { Effect }\end{array}$ & Estimated S.E. \\
\hline $\begin{array}{l}\text { Short process patent } \\
(<15 \text { years })\end{array}$ & -0.010 & 0.011 & -0.011 & 0.010 \\
\hline $\begin{array}{l}\text { Add long process } \\
\text { (only) patents }\end{array}$ & 0.034 & 0.015 & 0.033 & 0.016 \\
\hline $\begin{array}{l}\text { Add short product } \\
\text { patents }(<15 \text { years })\end{array}$ & 0.010 & 0.015 & 0.021 & 0.014 \\
\hline $\begin{array}{l}\text { Add long process \& } \\
\text { product patents }\end{array}$ & 0.006 & 0.012 & 0.008 & 0.009 \\
\hline Some price control & -0.005 & 0.012 & 0.014 & 0.011 \\
\hline Extensive price control & -0.028 & $\mathbf{0 . 0 1 0}$ & -0.029 & 0.013 \\
\hline Essential Drug List & -0.017 & 0.007 & $-0.017 *$ & $0.009^{*}$ \\
\hline Other Variables & & & & \\
\hline $\begin{array}{l}\text { Health expenditure share } \\
\text { Of GDP } 1995 / 97\end{array}$ & & & 0.272 & 0.246 \\
\hline Health expenditure & & & $0.041^{*}$ & $0.022 *$ \\
\hline LnPopulation & -0.257 & 0.120 & 0.024 & 0.005 \\
\hline LnGDPcapita & -0.063 & 0.020 & 0.109 & 0.028 \\
\hline Gini Coefficient & & & 0.016 & 0.006 \\
\hline Gini*LnGDPcapita & & & -0.002 & 0.0007 \\
\hline Pct $65 \mathrm{yrs}+$ & 0.877 & 1.746 & 0.567 & 0.265 \\
\hline Pct $15-64$ yrs & 0.219 & 0.246 & -0.279 & 0.119 \\
\hline Population Growth & & & -0.401 & 0.430 \\
\hline GDP Growth & & & 0.022 & 0.056 \\
\hline Radios per capita 1990 & & & -0.004 & 0.003 \\
\hline Growth Radios 90-95 & & & -0.004 & 0.005 \\
\hline Doctors/1000 in 1990 & & & 0.011 & 0.005 \\
\hline Growth Doctors 90-95 & & & -0.0007 & 0.002 \\
\hline $\begin{array}{l}\text { No. Obs./ Observed P } \\
\text { Pseudo } \mathrm{R}^{2}\end{array}$ & \multicolumn{2}{|c|}{$\begin{array}{l}19901 / 0.089 \\
0.155\end{array}$} & \multicolumn{2}{|c|}{$\begin{array}{c}17917 / 0.091 \\
0.132\end{array}$} \\
\hline $\begin{array}{l}\text { Notes: All specification } \\
\text { robust estimated standard } \\
\text { the disturbances in specif } \\
\text { coefficients significant a } \\
\text { variables means (all data } \\
\text { result of missing inequali } \\
\text { dropped in estimations wi }\end{array}$ & $\begin{array}{l}\text { control for } y \\
\text { rrors allow } \mathrm{f} \\
\text { ations withou } \\
\alpha=0.05 \text { an } \\
\text { and for a dis } \\
\text { information, } \\
\text { out country } F\end{array}$ & $\begin{array}{l}\text { ar of first launch } \\
\text { heteroscedasticity } \\
\text { country fixed effe } \\
0.10 \text {, respectively } \\
\text { ete change in the } \\
\text { ebanon, Puerto Ri }\end{array}$ & $\begin{array}{l}\text { nd therapy } \\
\text { and intra-co } \\
\text { ts. Bold type } \\
\text { Marginal e } \\
\text { ase of dumn } \\
\text { o, Saudi Ara }\end{array}$ & $\begin{array}{l}\text { ss. Huber-White } \\
\text { try correlation in } \\
\text { ce and * indicate } \\
\text { cts estimated at } \\
\text { variables. As a } \\
\text { and Taiwan are }\end{array}$ \\
\hline
\end{tabular}




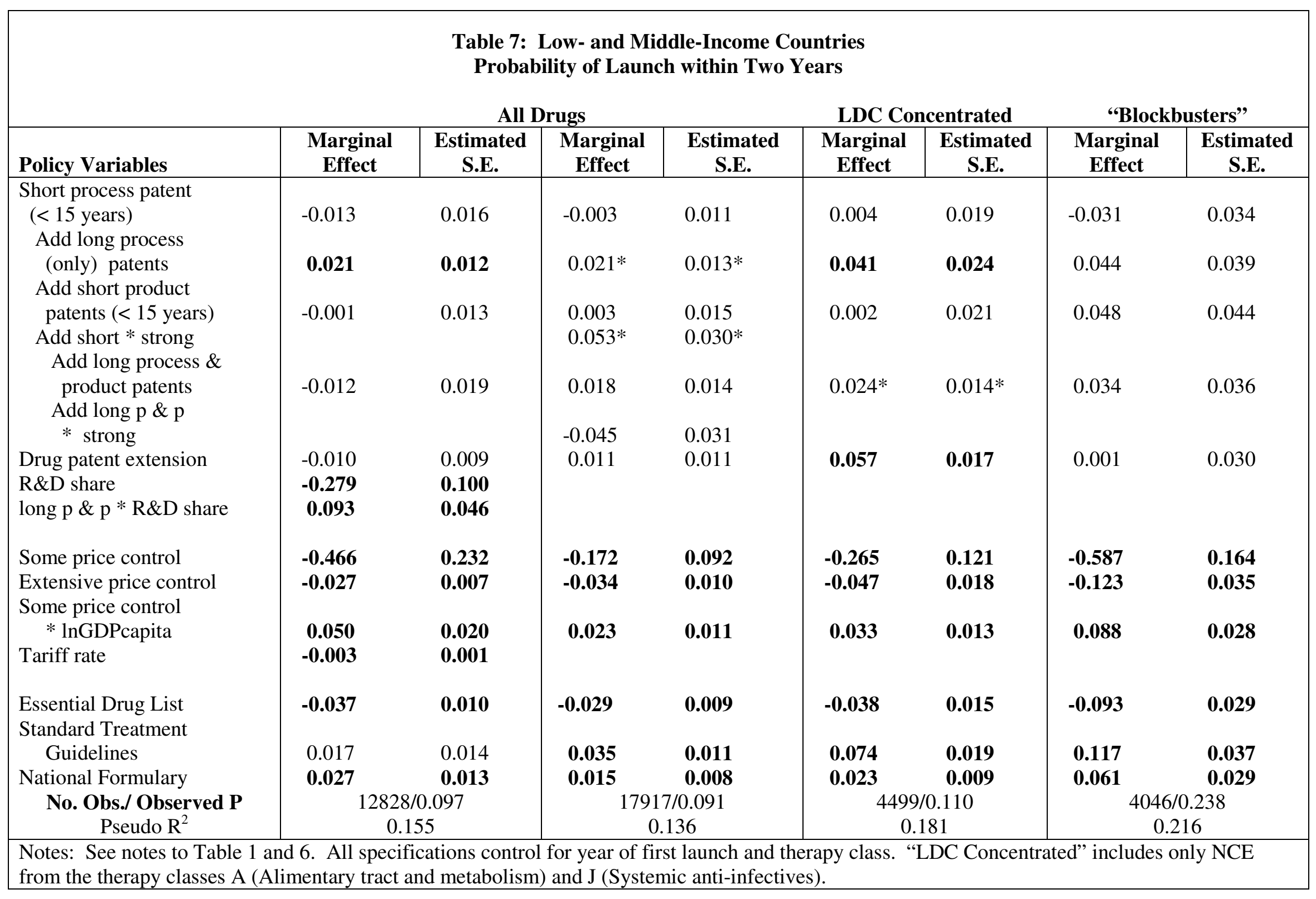




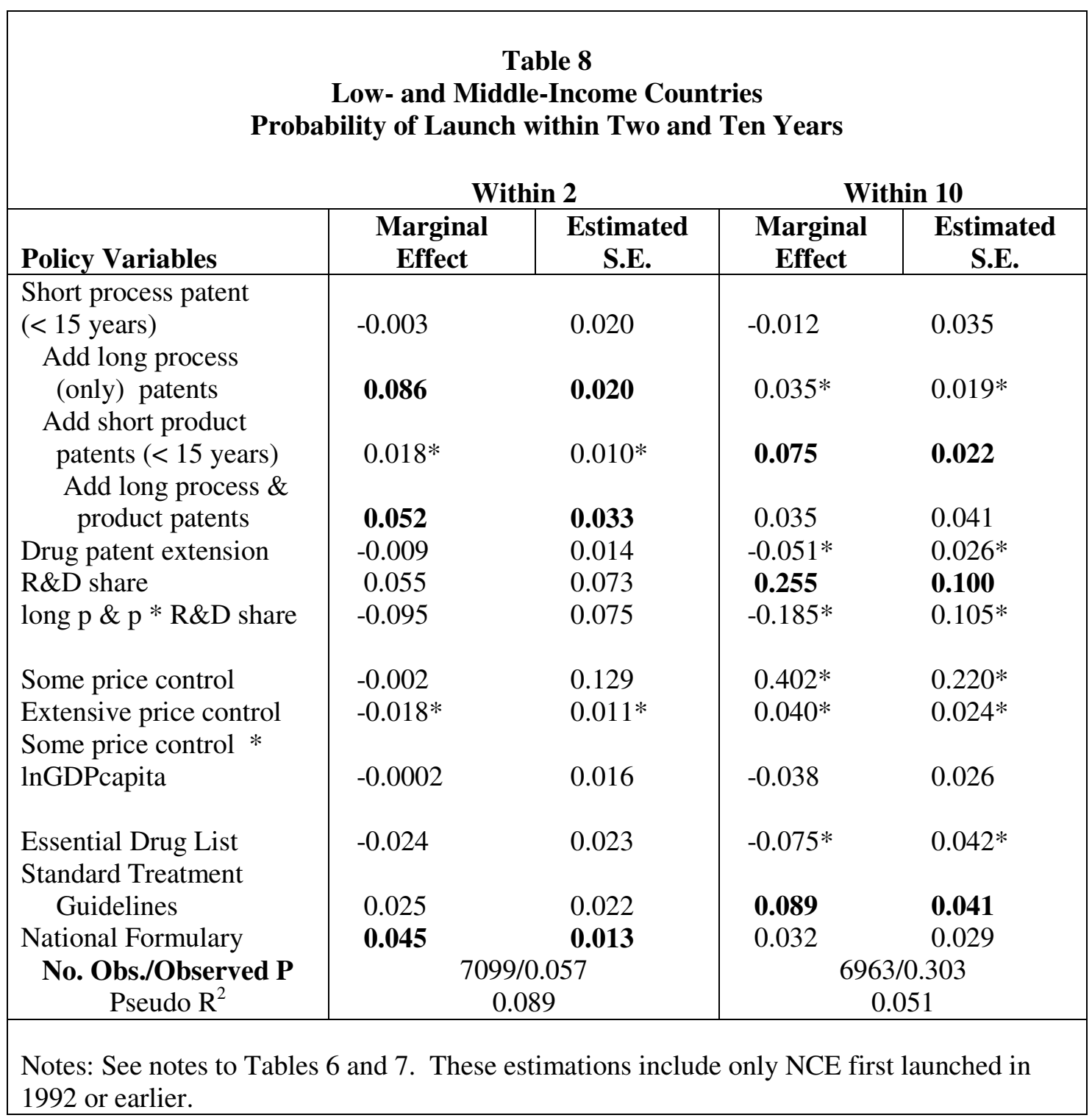




\begin{tabular}{|c|c|c|c|c|}
\hline \multicolumn{5}{|c|}{$\begin{array}{c}\text { Table 9: Hazard Estimations } \\
\text { Low- and Middle-Income Countries }\end{array}$} \\
\hline & \multicolumn{2}{|c|}{ All Data } & \multicolumn{2}{|c|}{ "Blockbusters" } \\
\hline Policy Variables & Coefficient & $\begin{array}{c}\text { Estimated } \\
\text { S.E. }\end{array}$ & Coefficient & $\begin{array}{l}\text { Estimated } \\
\text { S.E. }\end{array}$ \\
\hline \multirow{4}{*}{$\begin{array}{l}\text { Short process patent (<15 years) } \\
\text { Add long process } \\
\text { (only) patents } \\
\text { Add short product }\end{array}$} & 0.066 & 0.103 & 0.144 & 0.112 \\
\hline & & & & \\
\hline & -0.226 & 0.103 & $-0.208 *$ & $0.111^{*}$ \\
\hline & & & & \\
\hline patents $(<15$ years $)$ & -0.243 & 0.121 & -0.125 & 0.127 \\
\hline $\begin{array}{l}\text { Add long process \& } \\
\text { product patents }\end{array}$ & 0.053 & 0.095 & 0.022 & 0.101 \\
\hline Drug patent extension & -0.003 & 0.094 & -0.052 & 0.107 \\
\hline Some price control & 0.133 & 0.103 & 0.024 & 0.115 \\
\hline Extensive price control & 0.343 & 0.097 & 0.345 & 0.108 \\
\hline Essential Drug List & $0.111^{*}$ & $0.061^{*}$ & 0.065 & 0.063 \\
\hline Standard Treatment Guidelines & 0.020 & 0.070 & 0.100 & 0.073 \\
\hline \multicolumn{5}{|l|}{ Control Variables } \\
\hline LnPopulation & 3.466 & 1.023 & 3.182 & 1.130 \\
\hline LnConsumption & 0.526 & 0.178 & 0.154 & 0.188 \\
\hline Pct 65 yrs + & $22.823 *$ & $13.239 *$ & 24.838 & 14.982 \\
\hline Pct $15-64$ yrs & -6.303 & 1.996 & -5.719 & 2.210 \\
\hline$\gamma$ & 0.556 & 0.012 & 0.481 & 0.012 \\
\hline$\theta$ & 3.275 & 0.160 & 0.214 & 0.047 \\
\hline $\begin{array}{c}\text { No. Observations. } \\
\text { Log likelihood }\end{array}$ & & & & \\
\hline $\begin{array}{l}\text { Notes: See notes to Tables } 1 \text { an } \\
\text { gamma distributed multiplicative } \\
\text { year, and therapy class fixed effect }\end{array}$ & $\begin{array}{l}\text { Both specifi } \\
\text { or to capture }\end{array}$ & $\begin{array}{l}\text { ons use a log } \\
\text { bserved heter }\end{array}$ & $\begin{array}{l}\text { sistic hazard } \\
\text { heity. They }\end{array}$ & $\begin{array}{l}\text { Inction with } \\
\text { clude countr }\end{array}$ \\
\hline
\end{tabular}




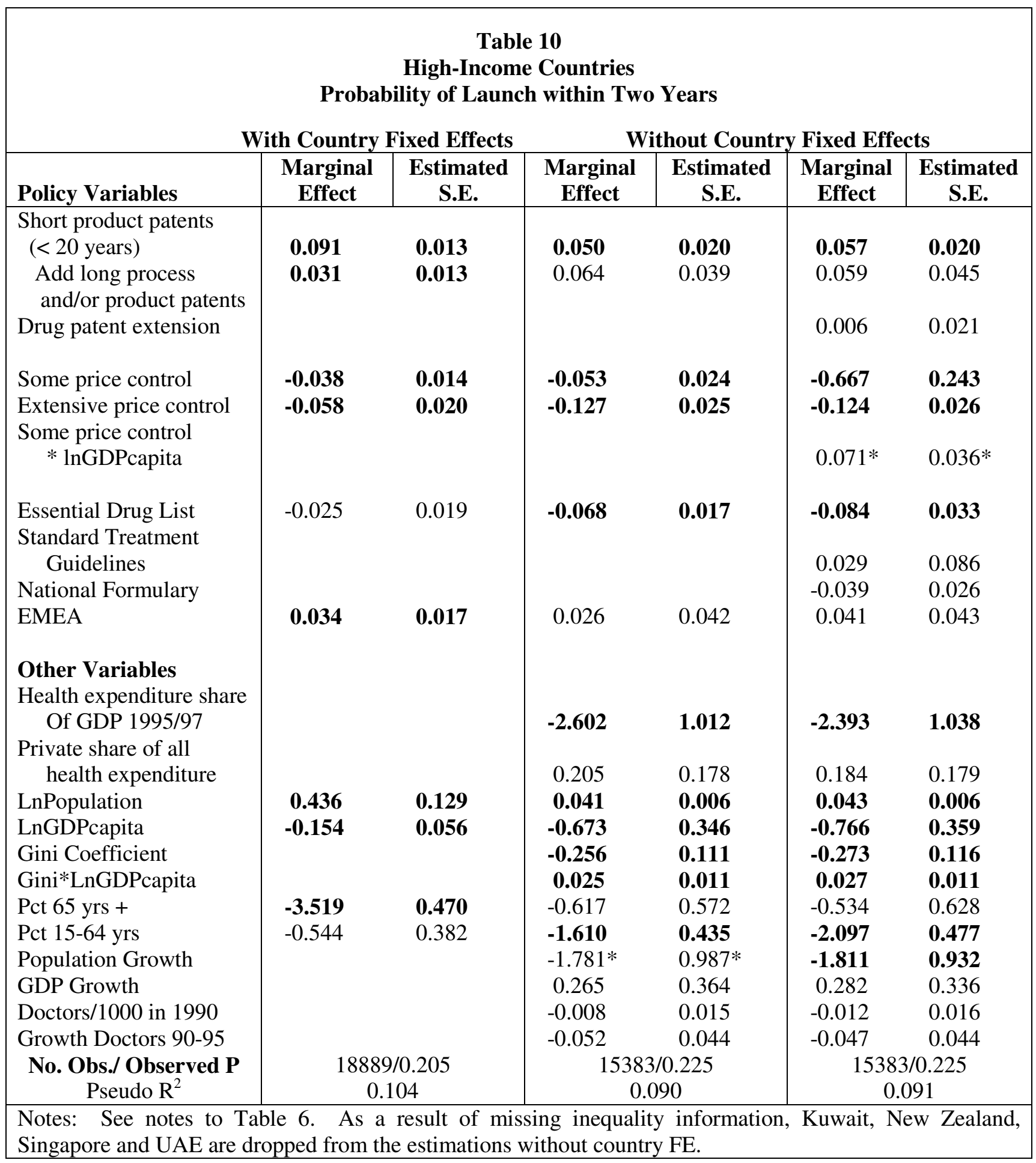




\begin{tabular}{|c|c|c|c|c|c|c|}
\hline \multicolumn{7}{|c|}{$\begin{array}{c}\text { Table } 11 \\
\text { High-Income Countries } \\
\text { Probability of Launch }\end{array}$} \\
\hline \multicolumn{3}{|c|}{ "High Quality Drugs" } & \multicolumn{4}{|c|}{ All Drugs } \\
\hline & \multicolumn{2}{|c|}{$\begin{array}{c}\text { With Country FE } \\
\text { Within } 2\end{array}$} & \multicolumn{2}{|c|}{ Within 2} & \multicolumn{2}{|c|}{ Within 10} \\
\hline Policy Variables & $\begin{array}{c}\text { Marginal } \\
\text { Effect }\end{array}$ & $\begin{array}{l}\text { Estimated } \\
\text { S.E. }\end{array}$ & $\begin{array}{c}\text { Marginal } \\
\text { Effect }\end{array}$ & $\begin{array}{l}\text { Estimated } \\
\text { S.E. }\end{array}$ & $\begin{array}{c}\text { Marginal } \\
\text { Effect }\end{array}$ & $\begin{array}{l}\text { Estimated } \\
\text { S.E. }\end{array}$ \\
\hline \multirow{3}{*}{$\begin{array}{l}\text { Short product } \\
\text { patents }(<20 \text { years }) \\
\text { Add long process } \\
\text { and/or product patents } \\
\text { Drug patent extension }\end{array}$} & 0.188 & 0.025 & 0.042 & 0.013 & -0.011 & 0.014 \\
\hline & \multirow[t]{2}{*}{0.035} & \multirow[t]{2}{*}{0.028} & 0.087 & 0.022 & \multirow{2}{*}{$\begin{array}{l}\mathbf{0 . 0 5 3} \\
0.025\end{array}$} & \multirow{2}{*}{$\begin{array}{l}\mathbf{0 . 0 2 1} \\
0.021\end{array}$} \\
\hline & & & -0.013 & 0.020 & & \\
\hline Some price control & \multirow{3}{*}{$\begin{array}{l}-0.056 \\
-0.107\end{array}$} & \multirow{3}{*}{$\begin{array}{l}0.029 \\
0.040\end{array}$} & $-0.379 *$ & $0.172 *$ & \multirow{2}{*}{$\begin{array}{l}\mathbf{- 0 . 6 3 8} \\
-0.055^{*}\end{array}$} & 0.128 \\
\hline \multirow{2}{*}{$\begin{array}{l}\text { Extensive price control } \\
\text { Some price control } \\
\quad * \text { lnGDPcapita }\end{array}$} & & & -0.095 & 0.017 & & $0.029 *$ \\
\hline & & & $0.041^{*}$ & $0.023 *$ & 0.077 & 0.024 \\
\hline Essential Drug List & 0.005 & 0.039 & -0.057 & 0.023 & -0.089 & 0.019 \\
\hline National Formulary & & & -0.022 & 0.018 & -0.010 & 0.028 \\
\hline EMEA & 0.088 & 0.031 & & & & \\
\hline $\begin{array}{c}\text { No. Obs./ Observed P } \\
\text { Pseudo R }{ }^{2}\end{array}$ & $\begin{array}{r}795 \\
0\end{array}$ & $\begin{array}{l}.335 \\
13\end{array}$ & $\begin{array}{r}9258 \\
0 .\end{array}$ & $\begin{array}{l}.166 \\
58\end{array}$ & $\begin{array}{r}9258 \\
0 .\end{array}$ & $\begin{array}{l}.371 \\
0\end{array}$ \\
\hline $\begin{array}{l}\text { Notes: See notes to Table } \\
\text { U.K. within } 2 \text { years of fir } \\
\text { "All Drugs" are based onl }\end{array}$ & $\begin{array}{l}\text { "High Qu } \\
\text { lobal launc } \\
\text { n NCE firs }\end{array}$ & $\begin{array}{l}\text { ty" is the sub } \\
\text { The U.S. and } \\
\text { unched in } 19\end{array}$ & $\begin{array}{l}\text { of NCE the } \\
\text { K. are not }\end{array}$ & are marketed & $\begin{array}{l}\text { either the U } \\
\text { estimations. } \\
\text { country fix }\end{array}$ & $\begin{array}{l}\text { or the } \\
\text { esults for } \\
\text { effects. }\end{array}$ \\
\hline
\end{tabular}




\begin{tabular}{|c|c|c|c|c|c|c|c|c|}
\hline \multicolumn{9}{|c|}{$\begin{array}{c}\text { Table 12 } \\
\text { Predicted Probability of Launch within Two Years } \\
\text { "Blockbuster" or "High Quality" Drugs }\end{array}$} \\
\hline \multicolumn{4}{|c|}{ Policy Scenario } & \multicolumn{5}{|c|}{ Country } \\
\hline $\begin{array}{c}\text { Product } \\
\text { Patent }\end{array}$ & $\begin{array}{c}\text { "Long" } \\
\text { Patent Term }\end{array}$ & $\begin{array}{c}\text { Any Price } \\
\text { Control }\end{array}$ & $\begin{array}{l}\text { Extensive } \\
\text { Price } \\
\text { Control }\end{array}$ & Brazil & Egypt & Thailand & France & Canada \\
\hline No & No & Yes & No & 55.7 & 16.6 & 25.8 & 27.2 & 34.3 \\
\hline No & Yes & Yes & No & 66.3 & 24.5 & 35.5 & & \\
\hline Yes & Yes & Yes & No & 71.6 & 29.5 & 41.2 & 54.5 & 64.2 \\
\hline Yes & Yes & No & No & $\mathbf{7 3 . 0}$ & 30.9 & 42.9 & 60.7 & 68.3 \\
\hline Yes & Yes & Yes & Yes & $\mathbf{5 3 . 0}$ & 15.1 & 23.8 & 42.2 & 50.3 \\
\hline \multicolumn{4}{|c|}{ S.E. on final prediction } & 11.3 & 8.4 & 8.5 & $\begin{array}{c}1 \\
6.4 \\
\end{array}$ & 5.0 \\
\hline $\begin{array}{l}\text { Note: All sc } \\
\text { and middle- } \\
\text { and use time } \\
\text { Egypt, and } 7 \\
\text { differences. }\end{array}$ & $\begin{array}{l}\text { ios assume that } \\
\text { me group) are } d \\
\text { iant country ch } \\
\text { and; }>19 \text { years }\end{array}$ & $\begin{array}{l}\text { least short } p \\
\text { ned in notes } \\
\text { cteristics for } \\
r \text { France and }\end{array}$ & $\begin{array}{l}\text { ss patents a } \\
\text { ables } 1 \text { and } \\
5 \text {, and the a } \\
\text { lada. Bold t }\end{array}$ & $\begin{array}{l}\text { ilable. } \\
\text { he predi } \\
\text { ectives t } \\
\text { ce indic: }\end{array}$ & $\begin{array}{l}\text { Quality" } \\
\text { given ar } \\
\text { class. } \\
\text { mpariso }\end{array}$ & $\begin{array}{l}\text {-income gr } \\
\text { ed on a moc } \\
\text { ng" statutor } \\
\text { t likely repr }\end{array}$ & $\begin{array}{l}\text { and "Blo } \\
\text { ith count } \\
\mathrm{m} \text { is }>14 \\
\text { it statistic }\end{array}$ & $\begin{array}{l}\text { ter" (low- } \\
\text { ed effects } \\
\text { for Brazil } \\
\text { gnificant }\end{array}$ \\
\hline
\end{tabular}




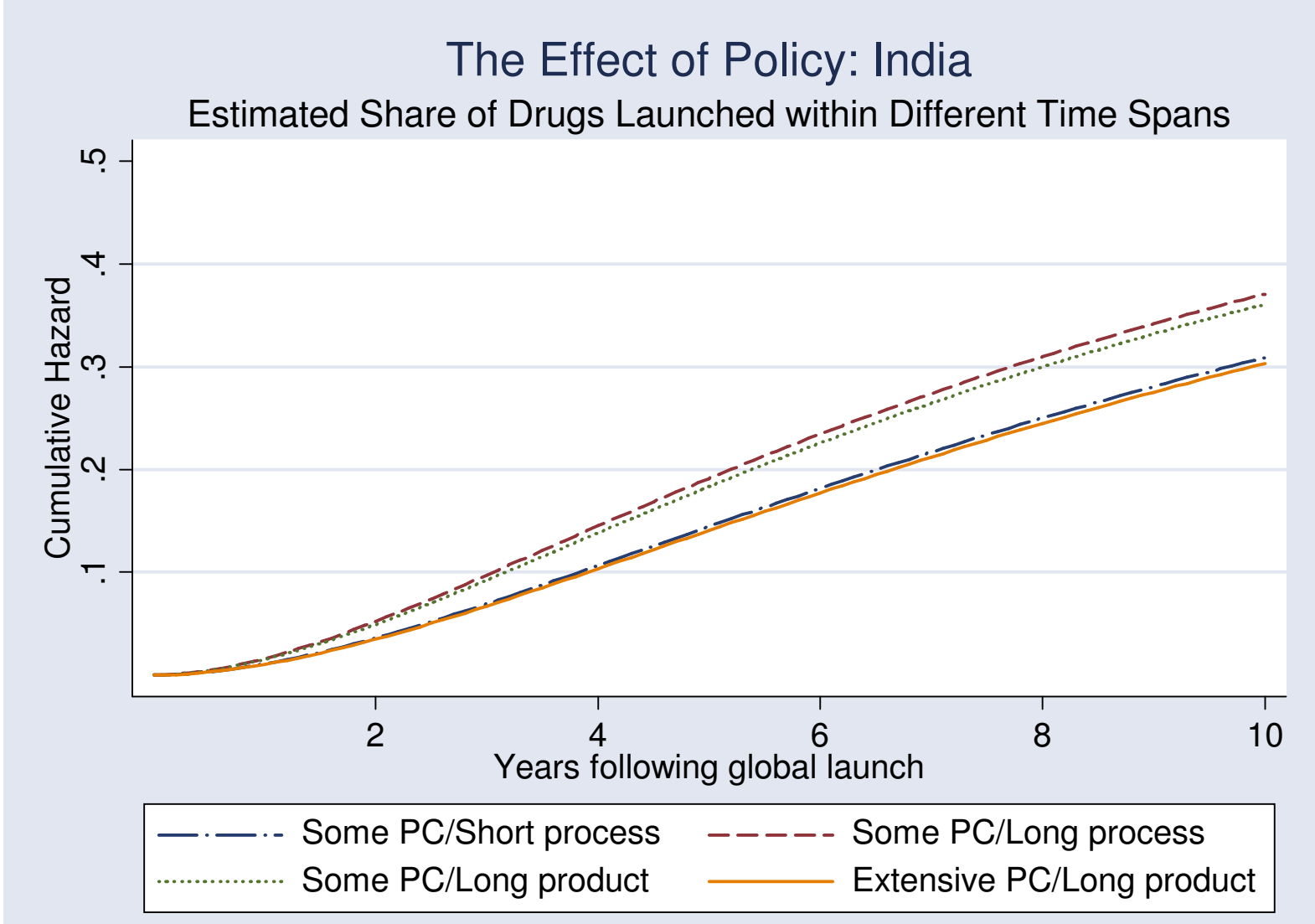

Figure 5 


\begin{tabular}{|c|c|c|}
\hline \multicolumn{3}{|c|}{$\begin{array}{c}\text { Table A1 } \\
\text { Launch Path for Ciprofloxacin }\end{array}$} \\
\hline \multicolumn{2}{|c|}{ Launch Within 2} & Lag \\
\hline PHILIPPINES & $10 / 1986$ & 0 \\
\hline GERMANY & $2 / 1987$ & 4 \\
\hline UK & $2 / 1987$ & 4 \\
\hline CENTRAL AMERICA & 9/1987 & 11 \\
\hline FINLAND & 9/1987 & 11 \\
\hline AUSTRIA & 9/1987 & 11 \\
\hline USA & $11 / 1987$ & 13 \\
\hline SWITZERLAND & $11 / 1987$ & 13 \\
\hline CHILE & $12 / 1987$ & 14 \\
\hline MEXICO & $12 / 1987$ & 14 \\
\hline AUSTRALIA & $1 / 1988$ & 15 \\
\hline SWEDEN & $2 / 1988$ & 16 \\
\hline NEW ZEALAND & $3 / 1988$ & 17 \\
\hline DENMARK & $4 / 1988$ & 18 \\
\hline JAPAN & $7 / 1988$ & 21 \\
\hline INDONESIA & $8 / 1988$ & 22 \\
\hline SPAIN & $8 / 1988$ & 22 \\
\hline THAILAND & $8 / 1988$ & 22 \\
\hline NETHERLANDS & 9/1988 & 23 \\
\hline PERU & $10 / 1988$ & 24 \\
\hline \multicolumn{3}{|c|}{ Launch Within 10} \\
\hline HONG KONG & $11 / 1988$ & 25 \\
\hline GREECE & $12 / 1988$ & 26 \\
\hline CANADA & $1 / 1989$ & 27 \\
\hline ISRAEL & 2/1989 & 28 \\
\hline IRELAND & $4 / 1989$ & 30 \\
\hline ARGENTINA & $4 / 1989$ & 30 \\
\hline ITALY & $5 / 1989$ & 31 \\
\hline COLOMBIA & $5 / 1989$ & 31 \\
\hline ECUADOR & $6 / 1989$ & 32 \\
\hline TURKEY & $6 / 1989$ & 32 \\
\hline PORTUGAL & $8 / 1989$ & 34 \\
\hline BRAZIL & $9 / 1989$ & 35 \\
\hline VENEZUELA & $9 / 1989$ & 35 \\
\hline FRANCE & $2 / 1990$ & 40 \\
\hline MALAYSIA & $3 / 1990$ & 41 \\
\hline BELGIUM & $3 / 1990$ & 41 \\
\hline SOUTH AFRICA & $6 / 1990$ & 44 \\
\hline INDIA & $8 / 1990$ & 46 \\
\hline PAKISTAN & $3 / 1991$ & 53 \\
\hline SAUDI ARABIA & $12 / 1991$ & 62 \\
\hline SINGAPORE & $7 / 1993$ & 81 \\
\hline EGYPT & $10 / 1994$ & 96 \\
\hline
\end{tabular}




\section{Table A2: Variable Definitions}

\begin{tabular}{|c|c|}
\hline $\begin{array}{l}\text { Short process patent } \\
(<15 \text { years })\end{array}$ & $\begin{array}{l}\text { Dummy = } 1 \text { if country protection only on pharmaceutical processes. When the } \\
\text { statutory term is defined to end "X years after grant," the granting process is } \\
\text { assumed to take } 2 \text { years. As is appropriate for some countries, we take the min or } \\
\text { max of "years from grant" and "years from filing" to estimate the statutory term. }\end{array}$ \\
\hline $\begin{array}{l}\text { Short product } \\
\text { patents }(<\mathrm{N} \text { years })\end{array}$ & Dummy $=1$ if product patents are offered. \\
\hline $\begin{array}{l}\text { Long process } \\
\text { (only) patents }\end{array}$ & $\begin{array}{l}\text { Dummy }=1 \text { if country offers only process patents with a statutory term } \geq 15 \\
\text { years. }\end{array}$ \\
\hline $\begin{array}{l}\text { Long process \& } \\
\text { product patents }\end{array}$ & $\begin{array}{l}\text { Dummy }=1 \text { if both product and process innovations covered and term is at least } \\
15 \text { years. }\end{array}$ \\
\hline $\begin{array}{l}\text { Long process and/or } \\
\text { product patents }\end{array}$ & $\begin{array}{l}\text { Dummy }=1 \text { if either process or both process and product protection is offered and } \\
\text { the term is at least } 20 \text { years. }\end{array}$ \\
\hline Strong & $\begin{array}{l}\text { "Strong" is a variable that takes on values between } 0 \text { and } 1 \text {, with a higher value } \\
\text { indicating that a country has more limits on how patent rights can be curtailed. }\end{array}$ \\
\hline Drug Patent Extension & $\begin{array}{l}\text { Dummy = } 1 \text { if firms may apply for an extension of the statutory term of patent } \\
\text { protection to compensate for time taken in the marketing approvals process. }\end{array}$ \\
\hline Some Price Control & $\begin{array}{l}\text { Dummy }=1 \text { if country has a formal price control mechanism but it is not } \\
\text { extensive. }\end{array}$ \\
\hline Extensive Price Control & $\begin{array}{l}\text { Dummy }=1 \text { if price control covers most of the market and/or is viewed as } \\
\text { particularly restrictive. }\end{array}$ \\
\hline Tariff & \\
\hline Essential Drug List & $=1$ for national adoption of an EDL \\
\hline $\begin{array}{l}\text { Standard Treatment } \\
\text { Guidelines }\end{array}$ & ummy = 1 for national adoption of standard treatment guidelines \\
\hline National Formulary & Dummy = 1 for having a national formulary \\
\hline EMEA & $\begin{array}{l}\text { Dummy }=1 \text { for years when a country is a member of the European Medicines } \\
\text { Evaluation Agency }\end{array}$ \\
\hline $\begin{array}{l}\text { Health Expenditure } \\
\text { Share of GDP } 1995 / 97\end{array}$ & Mean annual total health expenditure during the years $1995-97$ in 1995 U.S. \$ \\
\hline $\begin{array}{l}\text { Private Share of All } \\
\text { Health Expenditure }\end{array}$ & $\begin{array}{l}\text { Mean private health expenditure for } 1995-97 \text { as a share of mean total health } \\
\text { expenditure 1995-97 }\end{array}$ \\
\hline R\&D share & Country R\&D expenditure in all fields as share of GDP \\
\hline LnPopulation & population \\
\hline LnGDPcapita & Log of GDP per capita in 1995 U.S. \$ \\
\hline Gini Coeffic & $\begin{array}{l}\text { Estimated Gini coefficient of inequality (of household per-capita income in most } \\
\text { cases) taken as close as possible to early } 1990 \text { but ranging from years 1987-99. }\end{array}$ \\
\hline Pct 65 yrs + & Percentage of total population aged 65 and older \\
\hline Pct $15-64$ yrs & Percentage of total population aged 15 through 64 \\
\hline Population Growth & ct. Growth in total population over previous year \\
\hline GDP Growth & Pct. Growth in GDP over previous year \\
\hline Radios per capita 1990 & Average radios per person in 1990 \\
\hline Growth Radio 90-95 & Percent increase in radios per 100 between 1990 and 1995 \\
\hline Doctors/1000 in 1990 & Doctors per thousand people as of 1990/2 (1990 if available) \\
\hline Growth Doctors 90-95 & $\begin{array}{l}\text { Percent increase in doctors per thousand between } 1990 / 2 \text { and } 1995 / 7 \text { (1990 and } \\
1995 \text { if available) }\end{array}$ \\
\hline
\end{tabular}




\begin{tabular}{|c|c|c|c|c|c|c|c|c|}
\hline & \multicolumn{7}{|c|}{ Table A3: Variable Distributions } & \\
\hline & \multicolumn{4}{|c|}{ All Data } & \multicolumn{4}{|c|}{ Early Period (1982-93) } \\
\hline & \multicolumn{2}{|c|}{$\begin{array}{l}\text { Low/Middle } \\
\text { Income }\end{array}$} & \multicolumn{2}{|c|}{ High Income } & \multicolumn{2}{|c|}{$\begin{array}{l}\text { Low/Middle } \\
\text { Income }\end{array}$} & \multicolumn{2}{|c|}{ High Income } \\
\hline $\begin{array}{l}\text { Policy Variables } \\
\text { Process patent }\end{array}$ & $\begin{array}{c}\text { Mean } \\
0.853\end{array}$ & $\begin{array}{l}\text { S.D. } \\
0.345\end{array}$ & Mean & S.D. & $\begin{array}{l}\text { Mean } \\
0.752\end{array}$ & $\begin{array}{l}\text { S.D. } \\
0.422\end{array}$ & Mean & S.D. \\
\hline $\begin{array}{l}\text { Short product } \\
\text { patents }(<\mathrm{N} \text { years })\end{array}$ & 0.536 & 0.492 & 0.880 & 0.326 & 0.334 & 0.463 & 0.837 & 0.370 \\
\hline $\begin{array}{l}\text { Long process } \\
\text { (only) patents }\end{array}$ & 0.614 & 0.487 & & & 0.407 & 0.492 & & \\
\hline $\begin{array}{l}\text { Long process \& product } \\
\text { patents }\end{array}$ & 0.473 & 0.499 & & & 0.263 & 0.441 & & \\
\hline $\begin{array}{l}\text { Long process and/or } \\
\text { product patents }\end{array}$ & & & 0.779 & 0.415 & & & 0.693 & 0.461 \\
\hline Drug patent extension & 0.614 & 0.487 & 0.856 & 0.352 & 0.407 & 0.492 & 0.819 & 0.386 \\
\hline Some price control & 0.833 & 0.372 & 0.784 & 0.412 & 0.319 & 0.466 & 0.347 & 0.476 \\
\hline Extensive price control & 0.397 & 0.489 & 0.349 & 0.477 & 0.462 & 0.499 & 0.379 & 0.485 \\
\hline Tariff & 9.657 & 8.114 & & & 7.94 & 5.38 & & \\
\hline Essential Drug List & 0.415 & 0.490 & 0.921 & 0.270 & 0.131 & 0.335 & 0.884 & 0.321 \\
\hline $\begin{array}{l}\text { Standard Treatment } \\
\text { Guidelines }\end{array}$ & 0.178 & 0.373 & 0.972 & 0.164 & 0.082 & 0.272 & 0.957 & 0.204 \\
\hline National Formulary & 0.173 & 0.371 & 0.755 & 0.430 & 0.070 & 0.252 & 0.623 & 0.485 \\
\hline EMEA Member & & & 0.177 & 0.382 & & & & \\
\hline Control Variables & & & & & & & & \\
\hline R\&D share & 0.487 & 0.449 & & & 0.382 & 0.342 & & \\
\hline LnPopulation & 17.205 & 1.255 & 16.398 & 1.317 & 17.384 & 1.158 & 16.518 & 1.241 \\
\hline LnGDPcapita & 7.661 & 0.840 & 9.950 & 0.407 & 7.570 & 0.840 & 9.875 & 0.394 \\
\hline LnPop*LnGDPcapita & 131.49 & 13.74 & 163.31 & 15.74 & 131.20 & 13.22 & 163.23 & 15.23 \\
\hline Gini Coefficient & 43.677 & 10.235 & 32.453 & 6.188 & 45.530 & 9.402 & 32.710 & 6.217 \\
\hline Gini*LnGDPcapita & 334.43 & 95.99 & 322.84 & 58.41 & 345.98 & 95.07 & 322.79 & 57.66 \\
\hline Pct 65 yrs + & 0.053 & 0.031 & 0.128 & 0.033 & 0.043 & 0.017 & 0.125 & 0.027 \\
\hline Pct $15-64$ yrs & 0.600 & 0.005 & 0.666 & 0.027 & 0.582 & 0.035 & 0.665 & 0.028 \\
\hline Population Growth & 0.018 & 0.010 & 0.008 & 0.012 & 0.021 & 0.009 & 0.007 & 0.010 \\
\hline GDP Growth & 0.015 & 0.053 & 0.022 & 0.026 & 0.0109 & 0.0648 & 0.020 & 0.025 \\
\hline Radios per capita 1990 & 0.331 & 0.203 & 0.824 & 0.385 & 0.301 & 0.180 & 0.848 & 0.386 \\
\hline Growth Radios 90-95 & 0.136 & 0.425 & 0.139 & 0.934 & 0.157 & 0.474 & 0.039 & 0.067 \\
\hline Doctors/1000 in 1990 & 1.343 & 1.037 & 2.432 & 1.063 & 1.345 & 1.018 & 2.474 & 1.077 \\
\hline Growth Doctors 90-95 & 0.601 & 1.842 & 0.158 & 0.273 & 0.469 & 1.448 & 0.154 & 0.279 \\
\hline $\begin{array}{l}\text { Health Expenditure } \\
\text { Share of GDP 1995/97 }\end{array}$ & 0.054 & 0.019 & 0.080 & 0.019 & 0.053 & 0.019 & 0.081 & 0.018 \\
\hline $\begin{array}{l}\text { Private Share of All } \\
\text { Health Expenditure }\end{array}$ & 0.531 & 0.170 & 0.309 & 0.146 & 0.551 & 0.152 & 0.311 & 0.127 \\
\hline
\end{tabular}




\begin{tabular}{|c|c|c|c|c|c|c|c|c|c|c|}
\hline \multicolumn{11}{|c|}{$\begin{array}{l}\text { Table A4: Changes in Price Control and Patent Protection } \\
\text { Early Period (1982-92) and Late Period (1993-2000) }\end{array}$} \\
\hline & \multicolumn{2}{|c|}{$\begin{array}{l}\text { Any Price } \\
\text { Control }\end{array}$} & \multicolumn{2}{|c|}{$\begin{array}{l}\text { Extensive } \\
\text { Control }\end{array}$} & \multicolumn{2}{|c|}{$\begin{array}{l}\text { Process } \\
\text { Patents }\end{array}$} & \multicolumn{2}{|c|}{$\begin{array}{l}\text { Product } \\
\text { Patents }\end{array}$} & \multicolumn{2}{|c|}{$\begin{array}{l}\text { Statutory } \\
\text { Term }\end{array}$} \\
\hline & Early & Late & Early & Late & Early & Late & Early & Late & Early & Late \\
\hline $\begin{array}{l}\text { ARGENTINA } \\
\text { BANGLADESH } \\
\text { BOLIVIA } \\
\text { BRAZIL } \\
\text { BULGARIA } \\
\text { CENTRAL } \\
\text { AMERICA } \\
\text { CHILE } \\
\text { COLOMBIA } \\
\text { CZECH } \\
\text { REPUBLIC } \\
\text { DOMINICAN } \\
\text { REPUBLIC } \\
\end{array}$ & + & 0 & $\begin{array}{l}+ \\
0 \\
0 \\
0\end{array}$ & $\begin{array}{l}0 \\
0 \\
0 \\
0\end{array}$ & $\begin{array}{l}+ \\
+\end{array}$ & + & $\begin{array}{l}+ \\
+ \\
+\end{array}$ & + & + & $\begin{array}{l}+ \\
+\end{array}$ \\
\hline $\begin{array}{l}\text { ECUADOR } \\
\text { EGYPT } \\
\text { FRENCH WEST } \\
\text { AFRICA } \\
\text { HUNGARY } \\
\text { INDIA } \\
\text { INDONESIA } \\
\text { JORDAN } \\
\text { LATVIA } \\
\text { LEBANON } \\
\text { MALAYSIA } \\
\text { MEXICO } \\
\end{array}$ & $\begin{array}{l}+ \\
0 \\
+ \\
\end{array}$ & + & $\begin{array}{l}0 \\
0 \\
\\
0 \\
+ \\
+\end{array}$ & 0 & + & & + & $\begin{array}{l}+ \\
+\end{array}$ & + & $\begin{array}{l}+ \\
+ \\
+ \\
+ \\
+\end{array}$ \\
\hline $\begin{array}{l}\text { MOROCCO } \\
\text { PAKISTAN } \\
\text { PARAGUAY } \\
\text { PERU } \\
\text { PHILIPPINES } \\
\text { POLAND } \\
\text { PUERTO RICO } \\
\text { RUSSIA } \\
\text { SAUDI ARABIA } \\
\text { SLOVAK } \\
\text { REPUBLIC }\end{array}$ & 0 & + & $\begin{array}{l}0 \\
0 \\
0 \\
0\end{array}$ & & + & & + & $\begin{array}{l}+ \\
+\end{array}$ & + & $\begin{array}{l}+ \\
+ \\
+ \\
+ \\
+\end{array}$ \\
\hline $\begin{array}{l}\text { SOUTH AFRICA } \\
\text { SOUTH KOREA } \\
\text { TAIWAN } \\
\text { THAILAND } \\
\text { TUNISIA } \\
\text { TURKEY } \\
\text { URUGUAY } \\
\text { VENEZUELA } \\
\end{array}$ & + & + & & $\begin{array}{l}+ \\
0\end{array}$ & & + & + & $\begin{array}{l}+ \\
+ \\
+\end{array}$ & $\begin{array}{l}+ \\
+ \\
+\end{array}$ & $\begin{array}{l}+ \\
+ \\
+ \\
+ \\
\end{array}$ \\
\hline
\end{tabular}




\begin{tabular}{|c|c|c|c|c|c|c|c|c|c|c|}
\hline & \multicolumn{2}{|c|}{$\begin{array}{l}\text { Any Price } \\
\text { Control }\end{array}$} & \multicolumn{2}{|c|}{$\begin{array}{l}\text { Extensive } \\
\text { Control }\end{array}$} & \multicolumn{2}{|c|}{$\begin{array}{l}\text { Process } \\
\text { Patents }\end{array}$} & \multicolumn{2}{|c|}{$\begin{array}{l}\text { Product } \\
\text { Patents }\end{array}$} & \multicolumn{2}{|c|}{$\begin{array}{l}\text { Statutory } \\
\text { Term }\end{array}$} \\
\hline & Early & Late & Early & Late & Early & Late & Early & Late & Early & Late \\
\hline $\begin{array}{l}\text { AUSTRALIA } \\
\text { AUSTRIA } \\
\text { BELGIUM } \\
\text { CANADA } \\
\text { DENMARK } \\
\text { FINLAND } \\
\text { FRANCE } \\
\text { GERMANY } \\
\text { GREECE }\end{array}$ & $\begin{array}{l}+ \\
+ \\
+\end{array}$ & 0 &,+ 0 & + & & & $\begin{array}{l}+ \\
+\end{array}$ & + & + & + \\
\hline $\begin{array}{l}\text { HONG KONG } \\
\text { IRELAND } \\
\text { ISRAEL } \\
\text { ITALY } \\
\text { JAPAN } \\
\text { KUWAIT } \\
\text { LUXEMBOURG } \\
\text { NETHERLANDS } \\
\text { NEW ZEALAND } \\
\text { NORWAY } \\
\text { PORTUGAL }\end{array}$ & $\begin{array}{l}+ \\
+\end{array}$ & + & + & 0 & & & + & + & + & $\begin{array}{l}+ \\
+ \\
+\end{array}$ \\
\hline $\begin{array}{l}\text { SINGAPORE } \\
\text { SLOVENIA } \\
\text { SPAIN } \\
\text { SWEDEN } \\
\text { SWITZERLAND } \\
\text { UK } \\
\text { UNITED ARAB } \\
\text { EMIRATES } \\
\text { USA } \\
\end{array}$ & 0 & + & 0 & $\begin{array}{l}+ \\
0\end{array}$ & & & + & & & + \\
\hline
\end{tabular}




\begin{tabular}{|c|c|c|c|c|}
\hline \multicolumn{5}{|c|}{$\begin{array}{l}\text { Table A5: First-stage Regression Estimations } \\
\text { The Probability of Extensive Price Control }\end{array}$} \\
\hline \multicolumn{3}{|c|}{ Low- and Middle-income Countries } & \multicolumn{2}{|c|}{ High-income Countries } \\
\hline Variables & Coefficient & Estimated S.E. & Coefficient & Estimated S.E. \\
\hline LnPopulation & -0.008 & 0.023 & -0.059 & 0.021 \\
\hline LnGDPcapita & 0.024 & 0.158 & -3.908 & 0.563 \\
\hline Gini Coefficient & $-0.051 *$ & $0.031 *$ & -1.178 & 0.177 \\
\hline Gini*LnGDPcapita & 0.004 & 0.004 & 0.115 & 0.017 \\
\hline Pct 65 yrs + & -4.789 & 1.124 & 1.805 & 1.160 \\
\hline Pct $15-64$ yrs & -3.549 & 0.888 & -5.574 & 1.291 \\
\hline \multicolumn{5}{|l|}{ Instruments } \\
\hline Executive_right & 0.447 & 0.063 & $0.181 *$ & $0.105^{*}$ \\
\hline Executive_left & 0.376 & 0.064 & 0.369 & 0.105 \\
\hline Executive_center & 0.391 & 0.086 & 0.359 & 0.135 \\
\hline Executive_natl & -0.412 & 0.071 & & \\
\hline Tenure & 0.007 & 0.003 & 0.008 & 0.007 \\
\hline Military & 0.201 & 0.050 & & \\
\hline Budget Balance & -0.033 & 0.006 & 0.009 & 0.006 \\
\hline $\begin{array}{l}\text { Adjusted } R^{2} \\
\text { No. Obs. }\end{array}$ & \multicolumn{2}{|c|}{$\begin{array}{c}0.324 \\
435\end{array}$} & \multicolumn{2}{|c|}{$\begin{array}{c}0.292 \\
385\end{array}$} \\
\hline \multicolumn{5}{|c|}{$\begin{array}{l}\text { Notes: The first three instruments are dummies for the economic orientation of the party of the chief } \\
\text { executive. The fourth indicates if it is a nationalist party. Tenure is the number of years that the chief } \\
\text { executive has been in office. Military indicates if he is a military officer. Budget balance is overall, } \\
\text { including grants, as a percent of GDP. All instruments save tenure are lagged two years (as preferred } \\
\text { by data). Bold typeface and } * \text { indicate coefficients significant at } \alpha=0.05 \text { and } 0.10 \text {, respectively. } \\
\text { Sources: Political variables, the World Bank Database of Political Institutions, downloaded from } \\
\text { http://www.worldbank.org/research/bios/pkeefer.htm; Budget, World Development Indicators Online, } \\
2004 \text { (both accessed April 5, 2004). }\end{array}$} \\
\hline
\end{tabular}




\section{General References}

Bloom, Nicholas and John van Reenen (1998) "Regulating Drug Prices: Where Do We Go from Here?” Fiscal Studies, Vol. 19, no. 3, pp. 321-42.

Carpenter, Daniel, Brian Feinstein, Colin Moore, Marc Turenne, Ian Yohai and Evan James Zucker (2004) "Why do Bigger Firms Receive Faster Drug Approvals?" Mimeo. Department of Government, Havard University.

CDRI (1996). "Patents: Indian," Drugs and Pharmaceuticals: Industry Highlights. NISSAT. 19 (3 and 6), 35-39 and 43-48.

Chaudhuri, Shubham, Penelopi Goldberg and Panle Jai (2004) "Estimating the Effects of Global Patent Protection in Pharmaceuticals: A Case Study of Quinolones in India." Mimeo. Yale University.

Danzon, Patricia, Wang, Y. Richard and Liang Wang (2005) "The Impact of Price Regulation on the Launch Delay of New Drugs," Journal of Health Economics, Vol. 14, no. 3, pp. 269-92.

Dranove, David and David Meltzer (1994) "Do important drugs reach the market sooner," RAND Journal of Economics, Vol. 25, no. 3, pp. 402-23.

Ellison, Sara Fisher and Catherine Wolfram (2004) "Coordinating on Lower Prices: Pharmaceutical Pricing under Political Pressure." Mimeo. Haas School of Business, U.C. Berkeley.

Erfle, Stephen and Henry McMillan (1990) "Media, Political Pressure, and the Firm: The Case of Petroleum Pricing in the Late 1970s," The Quarterly Journal of Economics, pp. 115-34.

Gabrowski, Henry G. and John Vernon (2000) "Effective Patent Life in Pharmaceuticals," International Journal of Technology Management. Vol. 19, nos. 1/2, pp. 98-120.

Ganslandt, Matthias and Keith E. Maskus (2004) "The Price Impact of Parallel Imports in Pharmaceuticals: Evidence from the European Union," Journal of Health Economics, Vol. 23, no. 5, pp. 1035-57.

Glazer, Amihai and Henry McMillan (1992) "Pricing by the Firm Under Regulatory Threat," The Quarterly Journal of Economics, Vol. 107, no. 3, pp. 1089-99.

Jack, William and Jean O. Lanjouw (2005) "Financing Pharmaceutical Innovation: How Much Should Poor Countries Contribute?" World Bank Economic Review, forthcoming.

Kanavos, Panos, Joan Costa-i-Font, Sherry Merkur, Marin Gemmill (2004) "The Economic Impact of Pharmaceutical Parallel Trade in European Member States: A Stakeholder Analysis," Special Research Paper, LSE Health and Social Care, the London School of Economics and Political Science. 
King, John L. (2003) "Patent Examination Procedures and Patent Quality," in Wesley M. Cohen and Steven A. Merrill (eds.) Patents in the Knowledge-based Economy. (Washington D.C.: The National Academies Press).

Kyle, Margaret (2004a) "Pharmaceutical Price Controls and Entry Strategies," Mimeo. Fuqua School of Business, Duke University.

Kyle, Margaret (2004b) "The Role of Firm Characteristics in Pharmaceutical Product Launches," Mimeo. Fuqua School of Business, Duke University.

Lanjouw, J. O. (1998) "The Introduction of Product Patents in India: "'Heartless Exploitation of the Poor and Suffering'?” NBER Working Paper no. 6366.

Malueg, David and Marius Schwartz (1994) "Parallel imports, demand dispersion, and international price discrimination," Journal of International Economics, Vol. 37, pp. 167-95.

McCalman, Philip (2004) "International Diffusion and Intellectual Property Rights: An Empirical Analysis," Journal of International Economics. (forthcoming). Department of Economics, U.C. Santa Cruz.

Rivers, Douglas and Quang H. Vuong (1988) "Limited Information Estimators and Exogeneity Tests for Simultaneous Probit Models,” Journal of Econometrics. Vol. 39, pp. 347-66.

Sell, Susan (2003) Private Power, Public Law: the Globalization of Intellectual Property. Cambridge Studies in International Relations.

Scherer, F.M. and Jayashree Watal (2002) Post-TRIPS Options for Access to Patented Medicines in Developing Nations," Journal of International Economic Law, Vol. 5, pp. 913-939.

\section{Patent Law}

\section{Policy References}

Patents Throughout the World. Subscription updated looseleaf publication (New York: West Group).

World Patent Law and Practice: Patent Statutes, Regulations, and Treaties. John P. Sinnott and William Joseph Cotreau, eds. (New York: Matthew Bender \& Co., Inc. 1-800-833-9844.)

\section{Tariffs}

European Union (2003) "Working Document on Developing Countries' Duties and Taxes on Essential Medicines used in the Treatment of Infectious Diseases," DG Trade, EU. Ref. 135/03. Available at: http://europa.eu.int/comm/trade/issues/global/medicine/docs/wtosub_100303.pdf. 


\section{Pharmaceutical Regulation}

Ballance, R., J. Pogany, and H. Forstner. 1992. The World's Pharmaceutical Industries. An International Perspective on Innovation, Competition and Policy. United Kingdom: Edward Elgar Jacobzone.

Brudon, P. and C. Pénicaud. 1996. Le secteur pharmaceutique dans les pays de la zone CFA. WHO/DAP/95.8. Genèvre: Organisation mondiale de la Santé.

Chalmers, A., ed. 2002. International pharmaceutical registration. Denver, Colo.: Interpharm Press.

Cohen, J. C. 2000. Public Policies in the Pharmaceutical Sector: A Case Study of Brazil. World Bank LCSHD Paper Series No. 54. Washington, DC: World Bank.

Dag Hammarskjold Foundation. 1995. Making National Drug Policies a Development Priority: A Strategy Paper and Six Country Studies (Norway, Sri Lanka, Bangladesh, Australia, India, Mexico). Development Dialogue 1: 1-240.

Govindaraj, R. and G. Chellaraj. 2002. The Indian Pharmaceutical Sector: Issues and Options for Health Sector Reform. World Bank Discussion Paper no. 437. Washington, DC: World Bank.

Hill, Suzanne and Kent Johnson (2004) "Emerging Challenges and Opportunities in Drug Registration and Regulation in Developing Countries," Issues Paper - Access to Medicines. DIFD Health Systems Resource Centre.

Hogerzeil, H., et al. 1993. Field Tests for Rational Drug Use in Twelve Developing Countries. The Lancet 4 (December 1993): 1408-1410.

Huttin, C. 1999. Drug Price Divergence in Europe: Regulatory Aspects. Health Affairs 18 (May/June 1999): 245-9.

Jacobzone, S. 2000. Pharmaceutical Policies in OECD Countries: Reconciling Social and Industrial Goals. Organisation for Economic Co-operation and Development (OECD) Labor market and Social Policy, Occasional Papers No. 40.

Maksimova, L. 2001. Pharmaceutical Market in Russia. Industry Sector Analysis Series, U.S. Department of State.

Nambu, T., R. Rapp and R. Rozek. 1998. Regulatory Influences on the Decision to Introduce Pharmaceutical Products in Japan. The Journal of World Intellectual Property 1 September 1998.

Spivey, R., A. I. Wertheimer and T. D. Rucker, eds. 1992. International pharmaceutical services: the drug industry and pharmacy practice in twenty-three major countries of the world. New York: Pharmaceutical Products Press. 
World Health Organization (WHO). 2000. Policies on Pricing and Reimbursement of Medicines in Europe. Networking for Information Exchange among Policy-makers, WHO Regional Office for Europe.

. 1999. Troisième Rencontre des Ministres de la Santé des Pays africains de la zone franc et des pays associés sur la politique du medicament. WHO/EDM/DAP/99. Genèvre: Organisation mondiale de la Santé.

. 1997. Comparative analysis of national drug policies in 12 countries. WHO/DAP/97.6. Geneva: World Health Organization.

1998. Financing Drugs in South-East Asia. . Health Economics and Drugs DAP Series No. 8. Report of the second meeting of the WHO/SEARO Working Group on Drug Financing. Geneva: World Health Organization.

. 1994. Drug Pricing Systems in Europe, An Overview. WHO/EURO. Geneva: World Health Organization.

. 1992. Latin American Conference on Economic and Financial Aspects of Essential Drugs. Caracas, March 1992. WHO/DAP/92.8. Geneva: World Health Organization.

1990. Guiding Principles for Small National Drug Regulatory Authorities. WHO Expert Committee on Specifications for Pharmaceutical Products, Technical Report Series, no. 790. Geneva: World Health Organization.

World Bank. 2003. Turkey: Reforming the Health Sector for Improved Access and Efficiency. Sector Report, vol. 1 \& 2.

1997. The Hashemite Kingdom of Jordan Health Sector Study. World Bank Country Study. Washington, DC: World Bank.

Sarmiento, A. Z. 1995. Alternative Drug Pricing Policies in the Americas. WHO/DAP/95.6. Geneva: World Health Organization.

Madrid, I. 1998. Pharmaceuticals and health sector reform in the Americas: an economic perspective. Washington, D.C. : Action Programme on Essential Drugs, World Health Organization.

Fefer, E. 1996. Drug regulation in Latin America. Drug Policy Issues 20 March 1996. Boston, MA: Boston University.

, I. Madrid, and G. Velázquez. 1998. Pharmaceuticals and Health Sector Reform in the Americas: An Economic Perspective. Washington, D.C.: Pan American Health Organization and World Health Organization. 
and G. Velasquez, eds. 1991. Pharmaceutical in the Americas. WHO/HTP/EDM 99.1. Geneva: World Health Organization.

Whitaker, D. et al. 2002. Taiwan Pharmaceutical Price Gap: A Report for the PhRMA. National Economic Research Associates. London.

Petrova, G. 2002. Reform in the pharmaceutical sector in Balkan countries: critical moments. Faculty of Pharmacy, MU-Sofia.

Felker, G., et al. 1997. The Pharmaceutical Industry in India and Hungary. World Bank Technical Paper. Washington, DC: World Bank.

Kanji, N., et al. 1992. Drugs Policy in Developing Countries. London: Zed Books.

Lu, Z. J., et al. 1998. Strategic Pricing of New Pharmaceuticals. Review of Economics and Statistics n1 (February 1998): 108-18.

Frank, R. G., et al. 1995. Generic Entry and the Pricing of Pharmaceuticals. National Bureau of Economic Research Working Paper: 5306.

Litvack, J. I., D. S. Shepard, and J. D. Quick. 1989. Setting the Price of Essential Drugs: Necessity and Affordability. The Lancet 8659: 376-79

Redwood, H. 1993. Price Regulation and Pharmaceutical Research: The Limits of Co-Existence. Felixstow, Suffolk, UK: Oldwicks Press Limited.

Mossialos, E., C. Ranos, and B. Abel-Smith, eds. 1994. Cost Containment, Pricing and Pharmaceuticals in the European Community: The Policy-Makers' View. Athens: LSE Health and Pharmetrica SA.

Jommi, C. 2001. Pharmaceutical policy and organisation of the regulatory authorities in the main EU countries. Milano, EGEA.

Raymond, M. and S. Ueber. 1978. Health and policymaking in the Arab Middle East. Center for Contemporary Arab Studies. Washington, DC: Georgetown University.

United Nations (UN). 1976. Pharmaceuticals in Africa. United Nations Economic and Social Council, Economic Commission for Africa.

Gray, A., et al. 2002. Policy Change in a Context of Transition: Drug Policy in South Africa 1989-1999. Center for Health Policy, School of Public Health, University of Witwatersrand.

Department of Health. 1996. National Drug Policy for South Africa. Pretoria, South Africa.

Islam, N. 1989. Bangladesh National Drug Policy: An Assessment. Trop Doctor 19:18-20. 
Gallagher, E. N. 1990. Egypt's other wars: epidemics and the politics of public health. Syracuse, N.Y.: Syracuse University Press.

Chowdhury, Z. 1995. The politics of essential drugs: the makings of a successful health strategy: lessons from Bangladesh. N.J.: Zed Books.

Basant, R. 2001. Pharmaceutical Industry in Pakistan. Indian Institute of Management, Ahmedabad and the World Bank, Washington, DC.

Lee, M.B. 1994. The politics of pharmaceutical reform: the case of the Philippine National Drug Policy. International Journal of Health Services 1994; 24(3): 477-494.

Bulgakov, D. 2000. Pharmaceutical price limits set. The Russia Business Journal, 2 Sept 2000.

Schoonveld, E. 2002. Market Segmentation and International Price Referencing. Cambridge Pharma Consulting.

Dukes, G. and D. Broun. 1994. Pharmaceutical Policies: Rationale and Design. Human Resources Development and Operations Policy. HRO Working Papers No. 35. World Bank.

Danzon, P. M. 1997. Pharmaceutical price regulation: national policies versus global interests. Washington, D.C.: AEI Press.

and A. Towse. 2003. Differential pricing for pharmaceuticals: reconciling access, $\mathrm{R}$ \& D and patents. Washington, D.C.: AEI-Brookings Joint Center for Regulatory Studies.

and L. W. Chao. 2000. Cross-national price differences for pharmaceuticals: how large, and why? Journal of Health Economics 192000 159-195.

Jayasuriya, D.C. 1985. Regulation of pharmaceuticals in developing countries: legal issues and approaches. Geneva: Albany, NY : World Health Organization.

Wertheimer, A.I., and S. K. Grumer. 1992. Overview of International Pharmacy Pricing. PharmacoEconomics December 2(6): 449-55.

Burstall , M L. 1998. Pricing and Reimbursement in Western Europe 1998; A Concise Guide. A Pharma Pricing Review Report.

Rosian I., C.Habl and S. Vogler. 1998. Pharmaceuticals: Market control in nine European countries. Austrian Health Institute, Vienna.

Bala, K. and K. Sagoo. 2000. Patents and Prices. Health Action International. HAInews No 112 April/May 2000.

Gross, A. 1999. New Regulatory Trends in Thailand's Pharmaceutical Market. Report Date: March 1999. Pacific Bridge, Inc. 
PriceWaterhouseCoopers. 2002. Moscow Government Introduces New Pricing Regulations On Medicines. Tax Flash Report. Special Pharmaceuticals Issue No. 5, 4 June 2002

Ratanawijitrasin, S. and E. Wondemagegnehu. 2002. "Effective drug regulation: A multi-country study." Geneva: World Health Organization.

Health Care Systems in Transition: (various countries and years). European Observatory on Health Care Systems.

Kanavos, P. 2002. Financing Pharmaceuticals in Transition Economies. Department of Social Policy and LSE Health, London School of Economics and Political Science, London, UK.

. 2002. Pharmaceutical Pricing and Reimbursement in Europe. London, UK: PJB Publications.

. 2000. The Single Market for Pharmaceuticals in the European Union in Light of European Court of Justice Rulings. PharmacoEconomics, Vol. 18, No. 6, pp. 523-532, December 2000.

E. Mossialos, and M. Mrazek. 2000. Pharmaceuticals: A Global Industry with Local Interests. In Parsons, L. and G. Lister (eds.) Global Health: A local issue. The Nuffield Trust.

London School of Economic Study on Healthcare in Individual Countries: Worldwide Survey on Pharmaceutical Pricing and Reimbursement Structures. Commissioned by Enterprise Directorate-General of the European Commission.

Additional information was obtained from the health ministry websites of individual countries. 